\title{
Evaluation of antioxidant and anticancer activity of crude extract and different fractions of Chlorella vulgaris axenic culture grown under various concentrations of copper ions
}

Eman A. El-fayoumy ${ }^{1}$, Sanaa M. M. Shanab ${ }^{1}$, Hanan S. Gaballa², Mohamed A. Tantawy ${ }^{3}$ and Emad A. Shalaby ${ }^{2^{*}}$ (D)

\begin{abstract}
Background: Chlorella vulgaris is a microalga potentially used for pharmaceutical, animal feed, food supplement, aquaculture and cosmetics. The current study aims to study the antioxidant and prooxidant effect of Chlorella vulgaris cultivated under various conc. of copper ions.
\end{abstract}

Methods: The axenic green microalgal culture of Chlorella vulgaris was subjected to copper stress conditions ( 0.00 , $0.079,0.158,0.316$ and $0.632 \mathrm{mg} / \mathrm{L})$. The growth rate was measured at $\mathrm{OD}_{680} \mathrm{~nm}$ and by dry weight (DW).

Moreover, the Antioxidant activity against DPPH and ABTS radical, pigments and phytochemical compounds of the crude extracts (methylene chloride: Methanol, 1:1) were evaluated. The promising Cu crude extract (0.316 mg/L) further fractionated into twenty-one fractions by silica gel column chromatography using hexane, chloroform and ethyl acetate as a mobile phase.

Results: The obtained results reported that nine out of these fractions exhibited more than $50 \%$ antioxidant activity and anticancer activity against Hela cancer cell lines. Based on $I_{50}$, fraction No. 7 was found to be the most effective fraction possessing a significant increase in both antioxidant and anticancer potency. Separation of active compound (s) in fraction No 7 was performed using precoated silica gel plates $\left(T_{L C} F_{254}\right)$ with ethyl acetate: hexane $(9: 1 \mathrm{~V} / \mathrm{V})$ as mobile phase. Confirmation of active compound separation was achieved by two-dimensional TLC and visualization of the separated compound by UV lamp. The complete identification of the separated active compound was performed by UV-Visspectrophotometric absorption, IR, MS, H'-NMRT C ${ }^{13}$-NMR. The isolated compound ((2E,7R,11R)-3,7,11,15-Tetramethyl-2hexadecenol) have high antioxidant activity with $\mathrm{IC}_{50}(10.59 \mathrm{\mu g} / \mathrm{ml})$ against DPPH radical assay and comparable to the capacities of the positive controls, Butylated hydroxy toluene [BHT] $\left(\mathrm{IC}_{50} 11.2 \mu \mathrm{g} / \mathrm{ml}\right)$ and Vitamin $\mathrm{C}\left({ } \mathrm{C}_{50} 12.9 \mu \mathrm{g} / \mathrm{ml}\right)$. Furthermore, pure isolated compound exhibited a potent anticancer activity against Hela cell line with $\mathrm{IC}_{50}(4.38 \mathrm{\mu g} / \mathrm{ml})$ compared to Doxorubicin (DOX) as synthetic drug $(13.3 \mu \mathrm{g} / \mathrm{ml})$. In addition, the interaction of the pure compound with Hela cancer cell line and gene expression were evaluated.

(Continued on next page)

\footnotetext{
* Correspondence: dremad2009@yahoo.com

${ }^{2}$ Department of Biochemistry, Faculty of Agriculture, Cairo University, Giza 12613, Egypt

Full list of author information is available at the end of the article
}

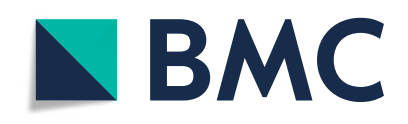

(- The Author(s). 2021 Open Access This article is licensed under a Creative Commons Attribution 4.0 International License, which permits use, sharing, adaptation, distribution and reproduction in any medium or format, as long as you give appropriate credit to the original author(s) and the source, provide a link to the Creative Commons licence, and indicate if changes were made. The images or other third party material in this article are included in the article's Creative Commons licence, unless indicated otherwise in a credit line to the material. If material is not included in the article's Creative Commons licence and your intended use is not permitted by statutory regulation or exceeds the permitted use, you will need to obtain permission directly from the copyright holder. To view a copy of this licence, visit http://creativecommons.org/licenses/by/4.0/. The Creative Commons Public Domain Dedication waiver (http://creativecommons.org/publicdomain/zero/1.0/) applies to the data made available in this article, unless otherwise stated in a credit line to the data. 
(Continued from previous page)

Conclusions: The authors recommend cultivation of Chlorella vulgaris in large scale under various stress conditions for use the crude extracts and semi purified fractions for making a pharmaco-economic value in Egypt and other countries.

Keywords: Chlorella vulgaris, Antioxidant and anticancer activity, Growth rate, Active ingredients

\section{Background}

An interest in the production of bioactive compounds from natural sources has lately emerged, driven by a growing number of scientific studies that demonstrate their beneficial effects on health [1-4]. In this regard, different bioactive compounds from natural sources can be used for the treatment of various human diseases such as anticancer, antibacterial, antiviral, antiinflammation, antioxidant ---etc. as reported by [5-11].

Several studies have been executed to investigate products of microalgae metabolism not only to understand its nature but also to explore substances with possible applications to humans in various fields of interest [12]. Chlorella $S p$ is a microalga potentially used for pharmaceutical, animal feed, food supplement, aquaculture and cosmetics [13-17]. It can be cultured and harvested easily, having short generation times enabling an environmentally friendly approach for drug discovery overcoming problems that associated with the over-vitalization of marine resources and use of distractive collection practices [18].

The algal extracts analysis has recently been studied for their significant efficiency in the hindrance of different diseases. However, only a few studies have been performed regarding the phytochemical, antioxidant, and pharmacological activities of algae [11, 17, 19, 20]. Cancer has become one of the world's leading adverse health effects with significant social and economic implications. Currently, cancer incidence rates account for one in seven deaths in the world, with far more deaths than tuberculosis, AIDS and malaria combined [17, 21]. Radiotherapy and chemotherapy for cancer therapeutics have many side effects such as the efficacy and non-specificity, chemo-resistance, and the responses of patients' immune systems. Natural compounds are an extremely valuable resource of biologically active moieties which play a major role in the quest for new drugs by acting as lead molecules for the discovery of new drug candidates [22]. At present, the percentage of drugs derived from natural sources with anticancer potential, is quite high corresponding to approximately $60 \%$ [23].

Microalgal compounds have been associated to immune response stimulation [24], as well as cytotoxic response against numerous cancer cell lines $[8,14]$.

The nutrimental factors are considered as manipulation of culture media composition (carbon source, nitrogen, phosphorus and iron deficiency), while physical is described as manipulation in operation conditions and external factors that affect the microalgae growth (high light intensities, temperature, $\mathrm{pH}$, salinity and electromagnetic fields) [25, 26].

Recently, several studies on the impact of multiple stresses including heavy metal exposure to microalgae growth was performed [27]. Algae often can minimize free radical damage inducing an antioxidant defensive system [28]. Both algal extracts and extracellular products have supported their antitumor, antioxidant, antimicrobial and antiviral activities [29]. $\mathrm{Cu}$ is considered an element which is vital growth of photosynthetic species. In high levels it become phytotoxic to cells, those significantly inhibit growth and lead to cell death [30]. $\mathrm{Cu}$ stress induced decrease in both pigment contents and growth rate in microalgae [31] and increasing the ROS generation through $\mathrm{Cu}$ interference in Fenton's reaction [28]. It rapidly attacks biomolecules (DNA, protein and lipid) leading to metabolic dysfunction and cell death [32].

The current study aims to evaluate the potential use of Chlorella vulgaris cultivated under $\mathrm{Cu}$ stress conditions as antioxidant in addition to its prooxidant effect with separation and identification of active ingredients. Furthermore, the expression of pro-apoptotic and anti-apoptotic genes were evaluated.

\section{Methods}

\section{Chemicals and reagents}

All organic solvents, silica gel, TLC $\left(\mathrm{F}_{254}\right)$ were purchased from E. Merck Co. (Darmstadt, Germany). $\mathrm{DPPH}, \mathrm{ABTS}^{+}$were purchased from Sigma-Aldrich (St. Louis, MO, USA). 


\section{Anticancer activity}

\section{Cell line cultures}

Human cervical cancer (Hela) was obtained and propagated in the center for genetic engineering, Faculty of Medicine, Al Azhar University, Egypt.

\section{Antioxidant kits}

Lipid peroxidation (MDA) colorimetric/ Fluorometric assay kit

Kit includes MDA lysis buffer, phosphotungestic acid solution, TBA, BHT and MDA standard.

\section{Gene expression}

\section{RNA extraction}

RNA was extracted from treated and untreated Hela cells after $48 \mathrm{~h}$ using Gene JET RNA purification kit according to the manufacturer's protocol.

2 Reverse transcription

Reverse transcription reaction mixture "QuantiTect Reverse Transcription kit"

3 Verification of cDNA synthesis: GAPDH specific control primers (designed to be complementary to human GAPDH genes) were used to verify the synthesis of cDNA produced from the extracted RNA.

4 Quantitative real-time Polymerase Chain Reaction (RT-PCR)

Evaluation of the expression of pro-apoptotic genes $\left(\mathrm{p}^{53}\right.$, Caspase 3 and $\mathrm{Bax}$ ) and anti-apoptotic genes (Bcl-2) using RT-PCR. Quantitative real-time PCR was performed on a Rotor-Gene $\mathrm{Q}$ cycler was carried out using the newly synthesized cDNA as templates for PCR and using QuantiTect SYBR Green PCR kits and forward and reverse primers for each gene.

22 The nucleic acid sequences of the primers were as follows

\begin{tabular}{lll}
\hline Gene & Forward primer & Reverse primer \\
\hline CASP- & 5'-TTC ATT ATT CAG GCC TGC & 5'-TTC TGA CAG GCC ATG \\
$3-$ & CGA GG- & TCA TCC TCA-3' \\
BCl-2 & 5'-CCTGTG GAT GAC TGA GTA & 5'-GAGACA GCC AGG AGA \\
& CC-3' & AAT CA-3' \\
Bax & 5'-GTTCATCCAGGATCGAG CAG- & 5'-CATCTCTTCCAGATGGT \\
& $3^{\prime}$ & GA-3' \\
$P^{53}$ & 5-'CCCCTCCTGGCCCCTGTCATCT & 5'-GCAGCGCCTCACAACCTC \\
& TC-3' & CGTCAT-3' \\
\hline
\end{tabular}

\section{Algal cultivation}

The green microalga Chlorella vulgaris used in this study was kindly isolated and identified by Dr. Sanaa Shanab, Professor of Phycology in the Department of Botany and Microbiology, Faculty of Science, Cairo University, according to [33, 34], then molecularly identified by sigma company (6th October, Egypt). The alga was cultivated on BG11 medium [35] and incubated at controlled culture conditions of temperature $\left(25 \pm 2{ }^{\circ} \mathrm{C}\right)$ light intensity $\left(40 \mu \mathrm{mol} \mathrm{m}^{-2}\right.$ $\mathrm{s}^{-1}$ ), light duration (16-8 L/D cycles) with continuous aeration (60bubbles/min.).

\section{Preparation of axenic culture (free from bacteria)}

Mixture of antibiotics; penicillium G, dihydrostreptomycin sulfate and gentamycin sulfate at different concentrations according to the method described by [36]. The axenic culture of the alga was used in all experimental work.

\section{Modification of the chemical composition of the culture medium}

Studying the effect of copper concentrations provided by the culture medium (BG11), an increase or decrease of certain element concentration was performed (as single element stress). copper concentrations were used as the following: Zero, $0.158,0.316$ and $0.632 \mathrm{mg} / \mathrm{L}$.

\section{Extraction of Chlorella vulgaris}

The dried algal biomass was extracted three times with organic solvent mixture of methanol and methylene chloride (1:1) for $40 \mathrm{~min}$ followed by centrifugation, filtration and evaporation of solvents using rotary evaporator at $40-50{ }^{\circ} \mathrm{C}$. The obtained crude extract was expressed as percentage of the dried biomass weight used (mg extract/g dry biomass weight).

\section{Fractionation of C.vulgaris $(0.316 \mathrm{~g} / \mathrm{L} \mathrm{Cu})$}

The chromatographic column $(40 \mathrm{~cm}$ length, $2.5 \mathrm{~cm}$ diameter) was packed with $150 \mathrm{~g}$ silica gel (60-120 mesh for column chromatography) using Hexane as solvent. 3 g of Methylene chloride: Methanol (1:1) crude extract of C.vulgaris cultivated under $0.316 \mathrm{mg} / \mathrm{L} \mathrm{Cu}$ (as promising crud extract) were grounded very well with some of silica gel powder and then placed on the top of the packed column. The column was then sequentially eluted with $100 \%$ Hexane and increased the polarity with chloroform followed by ethyl acetate, the polarity increased by $10 \%$ between each mobile phase mixtures (total 21 fractions were obtained) as the following: 


\begin{tabular}{|c|c|c|c|c|c|c|c|c|c|c|c|c|c|c|c|c|c|c|c|c|c|}
\hline \multirow[t]{2}{*}{ Solvent } & \multicolumn{21}{|c|}{ Fractions No. } \\
\hline & 1 & 2 & 3 & 4 & 5 & 6 & 7 & 8 & 9 & 10 & 11 & 12 & 13 & 14 & 15 & 16 & 17 & 18 & 19 & 20 & 21 \\
\hline Hexane & 100 & 90 & 80 & 70 & 60 & 50 & 40 & 30 & 20 & 10 & 0 & 0 & 0 & 0 & 0 & 0 & 0 & 0 & 0 & 0 & 0 \\
\hline Chloroform & 0 & 10 & 20 & 30 & 40 & 50 & 60 & 70 & 80 & 90 & 100 & 100 & 90 & 80 & 70 & 60 & 50 & 40 & 30 & 20 & 10 \\
\hline Ethyl acetate & 0 & 0 & 0 & 0 & 0 & 0 & 0 & 0 & 0 & 0 & 0 & 0 & 10 & 20 & 30 & 40 & 50 & 60 & 70 & 80 & 90 \\
\hline
\end{tabular}

\section{Biological activities of extract and fractions Antioxidant activity}

\section{- -DPPH radical scavenging activity}

The scavenging effect of algal extract and fractions were determined by the method of [37].

- ABTS radical cation scavenging assay.

This assay was based on the ability of different substances to scavenge (2, 2' - azino-bis ethylbenzthiazoline-6-sulfonic acid (ABTS ${ }^{+}$) according to method described by [38].

\section{Anticancer activity}

Cytotoxic effects of extract and fractions were tested against Hela cell lines (by MTT assay [39, 40] using 96well plate in triplicates and fractions were dissolved in DMSO were tested against Hela cell lines, Data were calculated as percentage of cell viability.

\section{Gas chromatography-mass spectrometry (GC/MS) analysis}

The chemical composition of promising algal extracts was performed using Trace GC1300-TSQ mass spectrometer (Thermo Scientific, Austin, TX, USA) with a direct capillary column TG-5MS $(30 \mathrm{~m} \times 0.25 \mathrm{~mm} \times$ $0.25 \mu \mathrm{m}$ film thickness). The components were identified by comparison of their retention times and mass spectra with those of WILEY 09 and NIST 11 mass spectral database.

\section{Prooxidant effect of pure Chlorella vulgaris compound}

\section{a. Determination of Reactive oxygen species}

Treated Hela cell line incubated with pure compound for $48 \mathrm{~h}$ was rinsed, homogenized in $20 \mathrm{ml}$ of $1 \mathrm{X}$ PBS and stored overnight at $\leq-20^{\circ} \mathrm{C}$ after two freeze-thaw cycles were performed to break the cell membranes, the homogenates were centrifuged for $5 \mathrm{~min}$ at $5000 \mathrm{rpm}$. Remove the supernatant and assay immediately or store at $\leq-20^{\circ} \mathrm{C}$ for determination of reactive oxygen species. Creation of a standard curve by plotting the mean absorbance for each standard on the $x$-axis against the concentration on the $y$-axis the data may be linearized by plotting the log of the ROS concentrations versus the $\log$ of the OD and the best fit line can be determined by regression analysis [41].

\section{b. Lipid Peroxidation (MDA)}

Hela cell line incubated with pure compound for $48 \mathrm{~h}$, it can be homogenized on ice in $300 \mu$ of MDA Lysis Buffer (with $3 \mu \mathrm{l} \mathrm{BHT} \mathrm{(100X),} \mathrm{then} \mathrm{centrifuged} \mathrm{(13,000} \mathrm{rpm.} \mathrm{For} 10$ min.) to remove insoluble material. Alternatively, protein can be precipitated by homogenizing $10 \mathrm{mg}$ sample in $150 \mu \mathrm{l}$ $\mathrm{ddH}_{2} \mathrm{O}+3 \mu \mathrm{l} \mathrm{BHT}$ and adding $1 \mathrm{vol}$ of $2 \mathrm{~N}$ perchloric acid, vortexing, and centrifuging to remove precipitated protein. Place $200 \mu \mathrm{l}$ of the supernatant from each sample into a microcentrifuge tube. Add $600 \mu \mathrm{l}$ of TBA reagent into each vial containing standards and sample. Incubate at $95^{\circ} \mathrm{C}$ for $60 \mathrm{~min}$. Cool to room temperature in an ice bath for $10 \mathrm{~min}$. Pipette $200 \mu \mathrm{l}$ (from each $800 \mu \mathrm{l}$ reaction mixture) into a 96well microplate for analysis occasionally, samples will exhibit a turbidity which can be eliminated by filtering through a $0.2 \mu \mathrm{m}$ filter. For colorimetric analysis, Read the absorbance at $532 \mathrm{~nm}$.

\section{iii. Gene expression}

RNA was extracted from each sample treated cell lines using nuclease free-water [42] and stored at $-70{ }^{\circ} \mathrm{C}$. Concentration and purity of the extracted RNA were determined according to manufacturer's protocol, where RNA was diluted with distilled water and the optical density was measured spectrophotometrically at 260 and $280 \mathrm{~nm}$ and the expected absorbance range of pure extracted RNA should be within 1.7 to 2.1 according to [43] For each sample, extracted RNA $(1 \mu \mathrm{g})$, random hexamer primer $(1 \mu \mathrm{l})$ and DEPC-treated water (to12 $\mu \mathrm{l})$ were mixed, centrifuged briefly and incubated at $65^{\circ} \mathrm{C}$ for $5 \mathrm{~min}$. Samples were placed on ice and the following components were added to each sample in the indicated order as recorded in "QuantiTect Reverse Transcription kit". The real-time PCR mixture was pre-denaturized at $94{ }^{\circ} \mathrm{C}$ for $3 \mathrm{~min} .35$ cycles with each cycle consisting of denaturation at $94{ }^{\circ} \mathrm{C}$ for $30 \mathrm{~s}$, followed by extension at $72{ }^{\circ} \mathrm{C}$ for $45 \mathrm{~s}$. Reactions were terminated by heating at $72{ }^{\circ} \mathrm{C}$ for $5 \mathrm{~min}$. Non-reverse transcribed RNAs were included to confirm the absence of genomic DNA. A negative control without adding template was also included to assess for reagent contamination RT-PCR product as $10 \mu \mathrm{l}$ was loaded on $1.5 \%$ agarose gel. Band 
detection was achieved at $100 \mathrm{~V}$ for $20-30 \mathrm{~min}$, using UV transilluminator and photographed after staining using Ethidium Bromide, PCR product should be visible at 496 bp [44].

\section{Thin layer chromatography}

The separation of active compound from the promising fraction of C.vulgaris was performed using precoated silica gel plates $\left(\mathrm{TLC} \mathrm{F}_{254}\right)$ using Hexane: ethyl acetate $(1: 9 \mathrm{v} / \mathrm{v})$ as mobile phase, the separated spot was scratched. Two dimensions TLC was used for confirmation the purity of this spot. Complete identification of the compound was performed using Mass Spectrum (MS), Infrared (IR) as well as Nuclear Magnetic Resonance Spectroscopy $\left({ }^{1} \mathrm{H}\right.$ NMR and ${ }^{13} \mathrm{C}$ NMR) as the following:

\section{Mass spectrum}

The bioactive compound separated from the promising fraction of the algal biomass crude extract was analyzed by Mass spectrum (MS) at Micro analytical center/ Faculty of Science Cairo University. The Mass spectrometer was scanned over the range of $40-500 \mathrm{~nm} / \mathrm{z}$ with an ionizing voltage of $70 \mathrm{ev}$ and identification was based on standard mass library of National Institute of Standard and Technology (NIST Version 2.0).

\section{Infrared spectrum}

Using Perkin Elmer 1430 infrared spectrophotometer $(400-4000 \mathrm{~nm})$, the molecular structure of the separated bioactive compound was partially identified through the presence of chemically active groups (functional groups).

\section{Ultraviolet - visible spectroscopy}

Ultraviolet - visible spectrophotometry related to the spectroscopy of photons in the UV- visible region. The separated compound was scanned from 400 to $500 \mathrm{~nm}$ range at $10 \mathrm{~nm}$ interval in the ultraviolet - visible spectrometer against solvent blank. The spectrum was recorded.

\section{$\mathrm{H}^{1}$-NMR and $\mathrm{C}^{13} \mathrm{NMR}$ nuclear magnetic resonance}

$\mathrm{H}^{1}$-NMR spectrum of the pure compound was performed by dissolving it in dimethyl sulfoxide (DMSO). The different protons of functional groups of the compound could be identified using $\mathrm{H}^{1}$-NMR (Varian Gemini $200 \mathrm{MHZ}$ ). $\mathrm{C}^{13} \mathrm{NMR}$ heteronuclear single quantum correction was carried out using the Brucker's standard pulse library.

\section{Statistical analysis}

All the data are expressed as mean \pm standard deviation of three determinations. Statistical comparison was performed via a one-way analysis of variance followed by
Duncan's multiple range test (DMRT). P- Values of less than $0.05(\mathrm{P}<0.05)$ were considered as significant.

\section{Results \\ Growth rate of Chlorella vulgaris cultivated under copper stress conditions}

Growth rate of C.vulgaris (OD and DW) under the influence of $\mathrm{Cu}$ concentrations was recorded. At zero $\mathrm{Cu}(\mathrm{Cu}$ depletion conditions) the alga grew well with a significant increase in growth parameters during the cultivation period, reached maximum at 25th day, except at day 30 where growth curve declined as shown in Fig. 1 ( $\mathrm{a}$ and b). Also, the obtained data revealed that relative decrease in growth at high $\mathrm{Cu}$ concentrations $(0.632 \mathrm{mg} / \mathrm{L})$ compared to those recorded at 0.158 and $0.316 \mathrm{mg} / \mathrm{L} \mathrm{Cu}$ especially towards the end of cultivation period (30 days) with $0.809-0.96 \%$ decrease from the growth values at $0.158 \mathrm{mg} / \mathrm{L} \mathrm{Cu}$ and of $0.54-0.55 \%$ decrease from the growth values at $0.316 \mathrm{mg} / \mathrm{L} \mathrm{Cu}$.

\section{Antioxidant activity of promising fractions of C.vulgaris}

Tables 1 and 2 tabulated the antioxidant activity of four promising fractions using ABTS and DPPH assays as a percentage of activity compared to both synthetic antioxidant (BHT) and natural standard (vitamin C), by determination of $\mathrm{IC}_{50}$ as $\mu \mathrm{g} / \mathrm{ml}$ for each fraction, fractions $[6,7]$ had the lowest $\mathrm{IC}_{50}$ (highest antioxidant activity) recorded 11.65 and $12.93 \mu \mathrm{g} / \mathrm{ml}$ respectively against DPPH radical assay and 14.2 and 17.75 against ABTS radical assay compared to both BHT $(11.2,15.1)$ and vitamin $\mathrm{C}(12.9,14.7 \mu \mathrm{g} / \mathrm{ml})$ against $\mathrm{DPPH}$ and ABTS assays respectively.

\section{Antioxidant and anticancer activities of the crude extract and fractions}

Figure 2 showed the antioxidant activity (as \%) of 21 fractions resulted from fractionation of the promising crude extract $(0.316 \mathrm{mg} / \mathrm{L} \mathrm{Cu} \mathrm{C.} \mathrm{vulgaris)} \mathrm{using} \mathrm{ABTS}$ assay. From the obtained results it was clear that, there were nine fractions gave high activity (more than 50\%) as the followings: (1, 4-8, 11-13, and). Whereas, fractions $1,6,7$ showed significantly $(p<0.05)$ the highest activity $(92.05 \pm 2.02 \%, 94.43 \pm 1.78 \%$ and $92.00 \pm$ $1.65 \%$ respectively).

The anticancer activity of nine fractions $(1,4-8,11-$ 13 , and) which recorded antioxidant activity more than $50 \%$ using ABTS radical scavenging method were examined against Hela cell line as a percentage of \% of cell viability as shown in Fig. 3.

A decline in $\mathrm{IC}_{50}$ (higher anticancer activity) of fractions compared to their crude extract $\left(\mathrm{IC}_{50}=\right.$ $90.2 \mu \mathrm{g} / \mathrm{ml}$ ) may be due to synergistic effects between bioactive compounds of fractions especially fraction $[6$, 7]. The promising active ingredients of the promising 


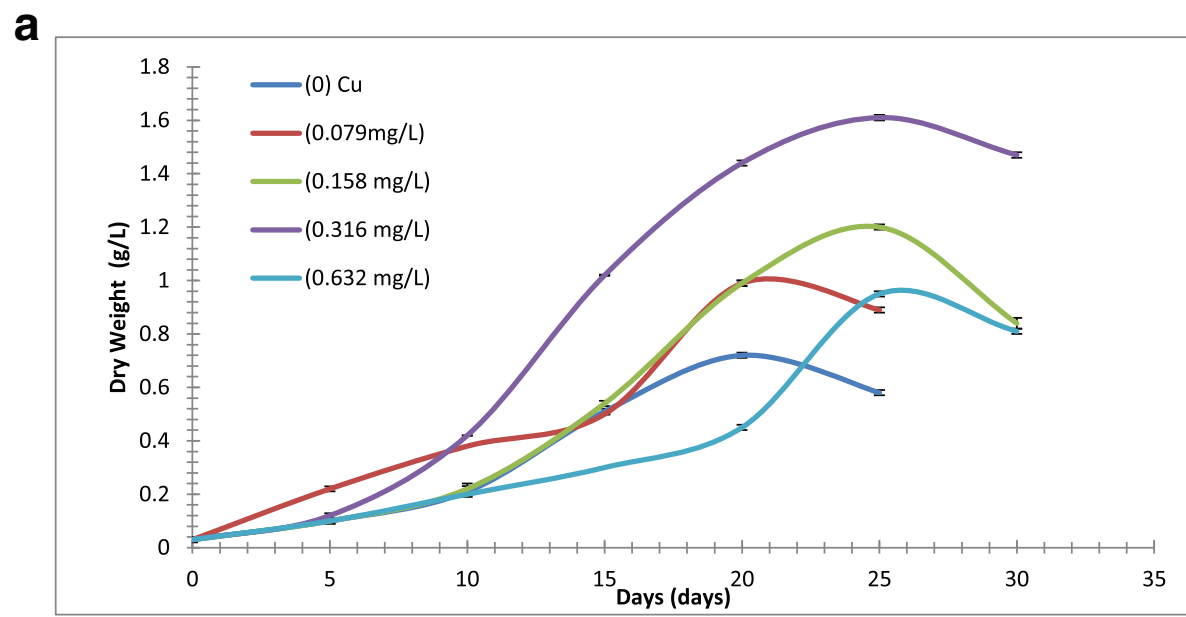

Growth curve of C.vulgaris (DW (g/L)) during 30 days of cultivation under

b different Copper concentrations (Mean of three replicates)

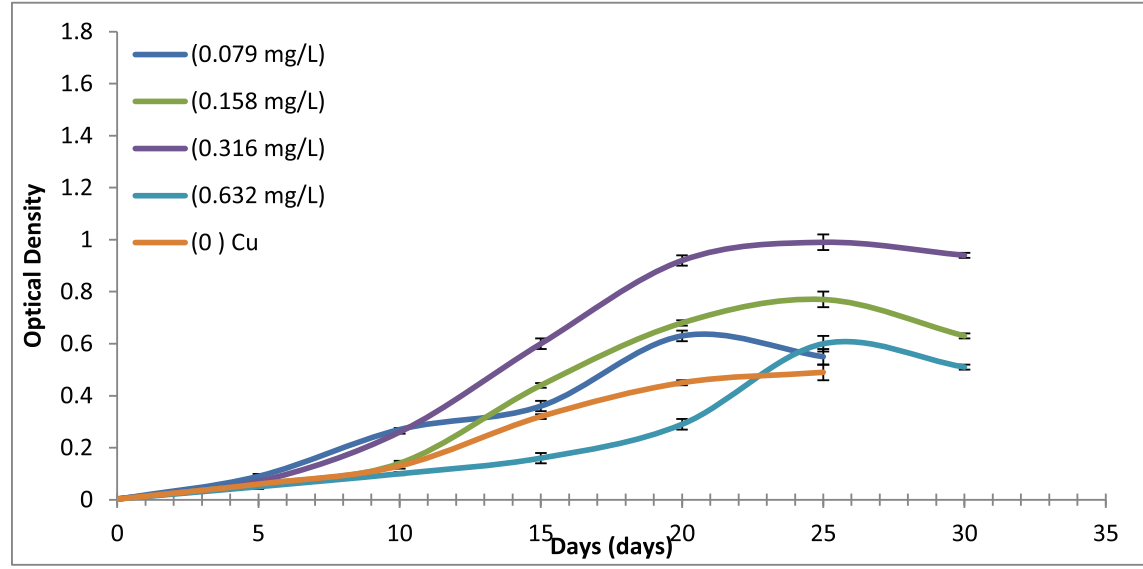

Growth curve of C.vulgaris (OD) during 30 days of cultivation under different Copper concentrations (Mean of three replicates).

Fig. 1 a Growth curve of C.vulgaris (DW (g/L)) during 30 days of cultivation under different Copper concentrations (Mean of three replicates). b Growth curve of C.vulgaris (OD) during 30 days of cultivation under different Copper concentrations (Mean of three replicates)

Table 1 Antioxidant activity (as $\%$ and $\mathrm{IC}_{50}$ ) of the four promising algal fractions from the crude extract from $\{(0.316 \mathrm{mg} / \mathrm{L}(\mathrm{Cu})$ of C.vulgaris compared to BHT and vitamin C as standards against ABTS (\%) radical method

\begin{tabular}{lllllll}
\hline $\begin{array}{l}\text { Fraction } \\
\begin{array}{l}\text { Conc. } \\
(\boldsymbol{\mu g} / \mathbf{m l})\end{array}\end{array}$ & $\begin{array}{l}\text { Hexane } \\
(\mathbf{1 0 0 \% )}\end{array}$ & $\begin{array}{l}\text { Hexane: } \\
\text { Chloroform } \\
(\mathbf{6 : 4 )}\end{array}$ & $\begin{array}{l}\text { Hexane: } \\
\text { Chloroform } \\
\mathbf{( 5 : 5 )}\end{array}$ & $\begin{array}{l}\text { Hexane: } \\
\text { Chloroform } \\
(\mathbf{4}: \mathbf{6})\end{array}$ & BHT & Vit.C \\
\hline $\mathbf{5 0 0}$ & $94.013 \pm 1.00^{\mathrm{a}}$ & $96.220 \pm 1.070^{\mathrm{a}}$ & $97.203 \pm 1.06^{\mathrm{a}}$ & $94.253 \pm 1.092^{\mathrm{a}}$ & $94.3 \pm 3.0^{\mathrm{a}}$ & $97.1 \pm 3.6^{\mathrm{a}}$ \\
$\mathbf{2 5 0}$ & $93.110 \pm 1.01^{\mathrm{a}}$ & $95.237 \pm 1.081^{\mathrm{a}}$ & $96.220 \pm 1.07^{\mathrm{a}}$ & $89.013 \pm 1.000^{\mathrm{b}}$ & $90.8 \pm 2.9^{\mathrm{b}}$ & $93.2 \pm 2.5^{\mathrm{b}}$ \\
$\mathbf{1 2 5}$ & $80.000 \pm 1.00^{\mathrm{b}}$ & $85.157 \pm 1.036^{\mathrm{b}}$ & $92.283 \pm 1.11^{\mathrm{b}}$ & $85.110 \pm 1.018^{\mathrm{c}}$ & $85.4 \pm 2.0^{\mathrm{c}}$ & $90.2 \pm 2.1^{\mathrm{c}}$ \\
$\mathbf{6 2 . 5 0}$ & $54.947 \pm 0.88^{\mathrm{c}}$ & $68.170 \pm 0.662^{\mathrm{c}}$ & $86.203 \pm 0.621^{\mathrm{c}}$ & $71.073 \pm 0.793^{\mathrm{d}}$ & $70.7 \pm 1.0^{\mathrm{d}}$ & $87.9 \pm 1.9^{\mathrm{d}}$ \\
$\mathbf{3 1 . 2 5}$ & $51.077 \pm 0.88^{\mathrm{d}}$ & $56.000 \pm 1.000^{\mathrm{d}}$ & $80.410 \pm 0.524^{\mathrm{d}}$ & $66.190 \pm 0.734^{\mathrm{e}}$ & $57.5 \pm 0.9^{\mathrm{e}}$ & $76.9 \pm 1.9^{\mathrm{e}}$ \\
$\mathbf{1 5 . 6 2}$ & $39.333 \pm 0.57^{\mathrm{e}}$ & $40.610 \pm 0.385^{\mathrm{e}}$ & $53.000 \pm 1.00^{\mathrm{e}}$ & $44.600 \pm 0.529^{f}$ & $51.8 \pm 0.9^{f}$ & $53.0 \pm 1.0^{f}$ \\
$\mathbf{I C}_{\mathbf{5 0}}$ & 19.85 & 19.52 & 14.2 & 17.75 & 15.1 & 14.7 \\
\hline
\end{tabular}

Different small letters on the column for each fraction indicate significant difference $(p<0.05)$. Error bars represent \pm SD of three replicates 
Table 2 Antioxidant activity (as \% and $\left.\mathrm{IC}_{50}\right)$ of the four promising algal fractions from the crude extract $\{(0.316 \mathrm{mg} / \mathrm{L}(\mathrm{Cu})$ of C.vulgaris compared to BHT and vitamin C as standards against DPPH (\%) radical method

\begin{tabular}{|c|c|c|c|c|c|c|c|c|c|c|c|c|}
\hline \multirow{2}{*}{$\begin{array}{l}\text { Fraction } \\
\text { Conc. } \\
\mu \mathrm{g} / \mathrm{ml} \text {. } \\
(\mu \mathrm{g} / \mathrm{ml})\end{array}$} & \multicolumn{2}{|c|}{$100 \%$ Hexane } & \multicolumn{2}{|c|}{$\begin{array}{l}\text { Hexane: } \\
\text { Chloroform } \\
(6: 4)\end{array}$} & \multicolumn{2}{|c|}{$\begin{array}{l}\text { Hexane:Chloroform } \\
(5: 5)\end{array}$} & \multicolumn{2}{|c|}{$\begin{array}{l}\text { Hexane: } \\
\text { Chloroform } \\
(4: 6)\end{array}$} & \multicolumn{2}{|l|}{ BHT } & \multicolumn{2}{|l|}{ Vit.C } \\
\hline & $30 \mathrm{~min}$. & $60 \mathrm{~min}$. & $30 \mathrm{~min}$. & $60 \mathrm{~min}$. & $30 \mathrm{~min}$. & $60 \mathrm{~min}$. & $30 \mathrm{~min}$. & $60 \mathrm{~min}$. & $30 \mathrm{~min}$. & $60 \mathrm{~min}$. & $30 \mathrm{~min}$. & $60 \mathrm{~min}$. \\
\hline 500 & $95.1 \pm 12.0^{\mathrm{a}}$ & $96.1 \pm 1.6^{\mathrm{a}}$ & $94.0 \pm 2.0^{\mathrm{a}}$ & $95.1 \pm 2.1^{\mathrm{a}}$ & $97.2 \pm 2.1^{\mathrm{a}}$ & $97.1 \pm 2.1^{\mathrm{a}}$ & $93.7 \pm 2.0^{a}$ & $92 . \pm 1.9^{a}$ & $96.3 \pm 1.5^{\mathrm{a}}$ & $97.4 \pm 3.0^{\mathrm{a}}$ & $93.4 \pm 1.1^{a}$ & $94.5 \pm 2.8^{a}$ \\
\hline 250 & $82 \pm 1.34^{b}$ & $80.5 \pm 1.8^{b}$ & $83.3 \pm 1.9^{b}$ & $82.6 \pm 1.9^{b}$ & $86 \pm 1.20^{b}$ & $85.7 \pm 1.9^{b}$ & $80 \pm 1.4^{b}$ & $81 . \pm 1.8^{\mathrm{b}}$ & $92.7 \pm 1.0^{b}$ & $93 \pm 2.2^{b}$ & $90.3 \pm 1.0^{b}$ & $90.9 \pm 2.2^{b}$ \\
\hline 125 & $77 \pm 1.08^{c}$ & $77.5 \pm 1.6^{c}$ & $74.5 \pm 1.7^{c}$ & $75.8 \pm 1.3^{c}$ & $84.0 \pm 81.5^{b}$ & $83.9 \pm 1.4^{c}$ & $78.5 \pm 2.0^{c}$ & $77.1 \pm 1.3^{c}$ & $90.3 \pm 0.9^{c}$ & $89.0 \pm 2.0^{c}$ & $88.8 \pm 0.9^{c}$ & $88.3 \pm 1.9^{c}$ \\
\hline 62.50 & $60.7 \pm 1.11^{d}$ & $61.1 \pm 1.7^{d}$ & $63.3 \pm 1.6^{d}$ & $64.8 \pm 1.3^{d}$ & $79.5 \pm 1.02^{c}$ & $80.7 \pm 1.9^{d}$ & $71 \pm 1.0^{d}$ & $70.9 \pm 1.9^{d}$ & $84.4 \pm 0.4^{d}$ & $84.9 \pm 2^{d}$ & $83.7 \pm 1.1^{d}$ & $85.9 \pm 1.0^{d}$ \\
\hline 31.25 & $59.3 \pm 0.9^{d}$ & $60.9 \pm 0.9^{d}$ & $56.3 \pm 1.1^{\mathrm{e}}$ & $55.1 \pm 1.1^{\mathrm{e}}$ & $74.4 \pm 1.2^{d}$ & $75.9 \pm 1.4^{e}$ & $60.3 \pm 0.9^{e}$ & $61.9 \pm 1.2^{\mathrm{e}}$ & $72.7 \pm 0.5^{\mathrm{e}}$ & $73.2 \pm 1.9^{\mathrm{e}}$ & $68.2 \pm 0.7^{e}$ & $69.5 \pm 0.9^{\mathrm{e}}$ \\
\hline 15.62 & $57.5 \pm 0.8^{\mathrm{e}}$ & $56.9 \pm 0.7^{e}$ & $53.5 \pm 1.2^{f}$ & $54.0 \pm 0.9^{e}$ & $65.8 \pm 1.3^{e}$ & $67.09 \pm 1 .{ }^{f}$ & $59.3 \pm 0.7^{e}$ & $60.4 \pm 1.1^{\mathrm{e}}$ & $70.2 \pm 0.8^{f}$ & $69.4 \pm 1.2^{f}$ & $64.4 \pm 0.5^{f}$ & $63.0 \pm 0.9^{f}$ \\
\hline $\mathrm{IC}_{50}$ & 13.58 & 13.72 & 14.59 & 14.46 & 11.87 & 11.65 & 13.18 & 12.93 & 11.1 & 11.2 & 12.1 & 12.9 \\
\hline
\end{tabular}

Different small letters on the column for each fraction indicate significant difference $(p<0.05)$. Error bars represent \pm SD of three replicates

fractions were identified using GC-MS, as shown in Table 3.

\section{Separation, characterization and identification of isolated bioactive compound}

Twenty-one Fractions were separated from Chlorella vulgaris (grown under $0.316 \mathrm{mg} / \mathrm{L}$ copper ion) crude extract (Fig. 2). Fraction No. 7 showed the highest biological activities as antioxidant and anticancer (Figs. 2 and 3). For separation of active compound(s) from fraction number 7, a Precoated TLC F254 and Ethyl acetate: Hexane (9:1) as mobile phase where be used. Additionally, two-dimension TLC was performed using different solvents combinations (9.5: 0.5, 9:1, 8.5:1.5 ethyl acetate: hexane respectively). The obtained pure compounds with $R_{f} 0.56$ and color ranged from yellow to orange (with maximum absorption at $445 \mathrm{~nm}$ ) was identified by different spectroscopic analyses. The obtained data of the spectroscopic analyses and colorimetric maximum absorption revealed that terpenoids derivative was identified with the common fragment ions: $57,71,85,149,169,221$ and $267 \mathrm{Da}$ and the molecular ion of $\mathrm{m} / \mathrm{e}=296$ is consistent with the molecular formula of $\mathrm{C}_{20} \mathrm{H}_{40} \mathrm{O}$ (Fig. $4 \mathrm{~d}$ ).

These results were confirmed by $\mathrm{H}^{1}-\mathrm{NMR}$ and $\mathrm{C}^{13}$ NMR. The $\mathrm{H}^{1}-\mathrm{NMR}$ data (Fig. $4 \mathrm{~A}$ and $\mathrm{B}$ ) which indicated that the pure compound had the following type of protons; A signal at $\delta 3.342 \mu \mathrm{g} / \mathrm{ml}$ was characteristic of protons of $\mathrm{O}-\mathrm{CH}_{2}$ group; the singlet signal at $\delta 2.490 \mu \mathrm{g} / \mathrm{ml}$ was characteristic of the protons of methylene $\left(\mathrm{CH}_{2}\right)$ group and the singlet signal at $\delta$ $1.221 \mu \mathrm{g} / \mathrm{ml}$ was characteristic of protons of methyl $\left(\mathrm{CH}_{3}\right)$ group. in addition, The $\mathrm{C}^{13}$-NMR data (Fig. 4b). indicated that the pure compound had the following type of carbons; A signal at $\delta 61.419 \mu \mathrm{g} / \mathrm{ml}$ was characteristic of $\mathrm{O}-\mathrm{CH}_{2}-\mathrm{R}$ group and the signal at $\delta 39.500 \mu \mathrm{g} /$

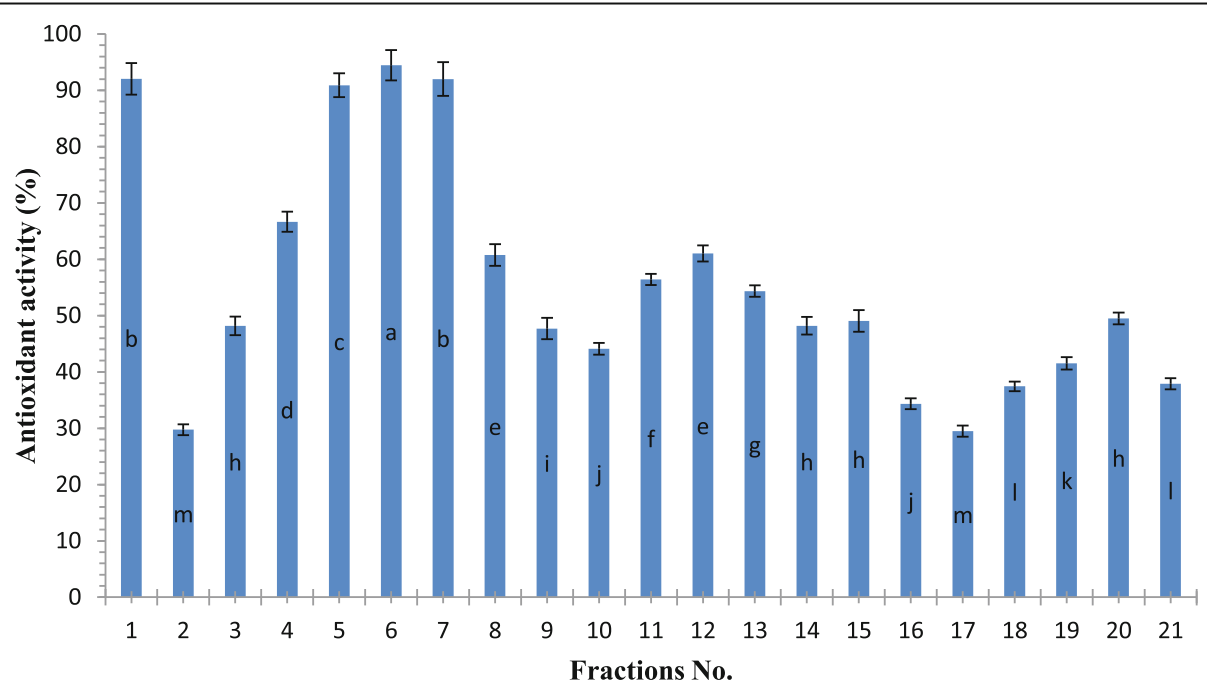

Fig. 2 Antioxidant activity (as \%) of 21 fractions at $200 \mu \mathrm{g} / \mathrm{ml}$ of the C. vulgaris $0.316 \mathrm{mg} / \mathrm{L}$ (Cu), using ABTS radical method 


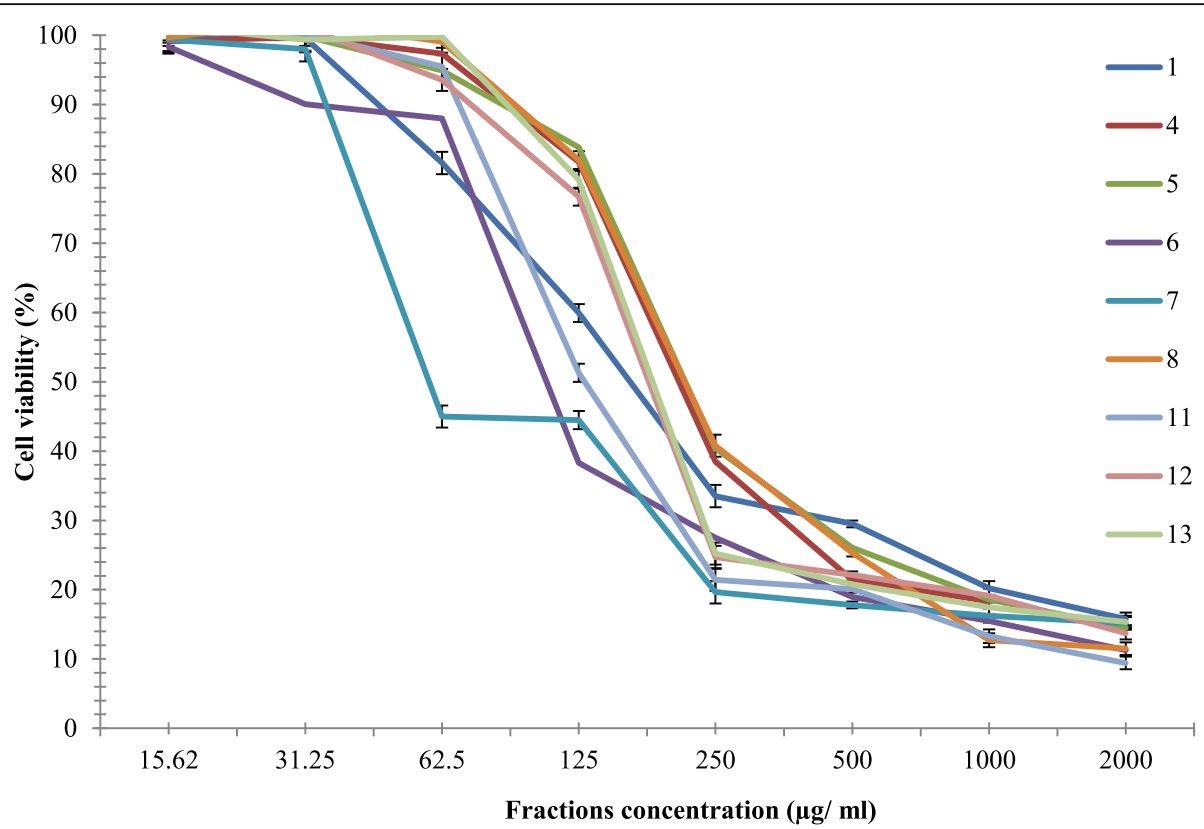

Fig. 3 Anticancer activity of the nine promising fractions from $0.316 \mathrm{mg} / \mathrm{L}(\mathrm{Cu})$ of C.vulgaris against cervical cell line (Hela cell line) as \% of cell viability (Mean of three replicates)

$\mathrm{ml}$ was characteristic of $\mathrm{R}-\mathrm{CH}_{2}$ - electronegative group. in addition, A signal at $\delta 29.008$ and $22.093 \mu \mathrm{g} / \mathrm{ml}$ was characteristic of $\mathrm{R}-\mathrm{CH}_{2}-\mathrm{R}$ group, However, A signal at $\delta$ $13.956 \mu \mathrm{g} / \mathrm{ml}$ was characteristic of $\mathrm{R}-\mathrm{CH} 3$ group. Also, FTIR was used to analyze the functional groups in the separated compound. In the FT-IR spectral analysis of pure compound from Chlorella vulgaris observed characteristic bands corresponding to $\mathrm{O}-\mathrm{H}$ stretching vibration at $3431.71 \mathrm{~cm}^{-1}$. The $\mathrm{C}-\mathrm{H}$ stretching was observed at 2923.56 and 2855.1. The absorption peaks at 1630 was assigned to $\mathrm{C}=\mathrm{C}$ group (Fig. $4 \mathrm{c}$ ). The obtained data indicated that the separated compound was exactly matched with the reported data for $(2 \mathrm{E}, 7 \mathrm{R}, 11 \mathrm{R})-3,7,11$, 15-Tetramethyl-2-hexadecenol (Fig. 4e). The MS spectrum of separated compound from C.vulgaris identified the common fragmental ions as: $57,71,85,149$, 169,221 and $267 \mathrm{Da}$ with molecular ion $\mathrm{m} / \mathrm{e}=296 \mathrm{Da}$ (as shown in Fig. 4d. Qualitative test was carried out on the pure compound showed a positive result for terpene (reddish brown color).

\section{Biological activities of isolated compound Antioxidant activity}

Table 4, recorded the antioxidant activity of pure compound compared to those synthetic antioxidant (BHT), and natural antioxidant (Vit. C), using DPPH radical assay, the results showed the higher antioxidant activity of pure compound with lower $\mathrm{IC}_{50}(10.59 \mu \mathrm{g} /$ $\mathrm{ml})$, compared to BHT $(11.2 \mu \mathrm{g} / \mathrm{ml})$, and Vit. C, $(12.9 \mu \mathrm{g} / \mathrm{ml})$ after $60 \mathrm{~min}$ of incubation.

\section{Anticancer activity and prooxidant effect}

Cytotoxicity of pure compound against Hela cell line recorded in Fig. 5 showed that, the viability of cancer cells mostly was affected by the lowest extract concentration $(100-0.1 \mu \mathrm{g} / \mathrm{ml})$ with $\mathrm{IC}_{50}(4.38 \mu \mathrm{g} / \mathrm{ml})$ compared to DOX as synthetic drug $(13.3 \mu \mathrm{g} / \mathrm{ml})$.

\section{Discussion}

This study revealed declined growth of C.vulgaris at high copper concentration $(0.632 \mathrm{mg} / \mathrm{L})$. It is worth noting that crude extract, fractions and pure compound from Chlorella sp. (grown under $0.316 \mathrm{mg} / \mathrm{L}$ copper ion) were investigated and the results revealed high potential for use of Chlorella vulgaris as antioxidant and anticancer sources against DPPH and Hela cell lines respectively.

The stimulatory effect of $\mathrm{Cu}$ at low concentration in this study may be due to its involvement in different metabolic processes or in the production of certain organic compounds that induce decreased $\mathrm{Cu}$ toxicity. These results coincided with those of both $[45,46]$, they suggested that some algae may synthesize metal binding compounds to sequester copper ions in the cytoplasm and reduced its toxicity as in Euglena gracilis and Thalassiosira pseudonana. However, the declined growth of C.vulgaris at high copper concentration may be due to the decreased resistance of C.vulgaris to tested $\mathrm{Cu}$ concentrations (from $0.158 \mathrm{mg} / \mathrm{L}$ to $0.632 \mathrm{mg} / \mathrm{L}$ ). Also, copper, seems to regulate the expression of functional activity as concentration factor for different 
Table $3 \mathrm{GC} /$ mass for most promising C. vulgaris fractions cultivated under $\mathrm{Cu}(0.316 \mathrm{mg} / \mathrm{L})$ as relative percentage

\begin{tabular}{|c|c|c|c|c|c|c|c|c|}
\hline \multirow[t]{2}{*}{ No. } & \multirow[t]{2}{*}{ Compound Name } & \multirow[t]{2}{*}{ M.wt } & \multicolumn{4}{|c|}{ (Fractions number) } & \multirow[t]{2}{*}{ Biological activity } & \multirow[t]{2}{*}{ Reference } \\
\hline & & & 1 & 5 & 6 & 7 & & \\
\hline 1 & $\begin{array}{l}4 \text { h-1-benzopyran-4-one, } \\
\text { 2-(3,4-dimethoxyphenyl)-3,5- } \\
\text { dihydroxy-7-methoxy- }\end{array}$ & 344 & & & & 5.87 & $\begin{array}{l}\text { Antioxidant, antimicrobial, cancer enzyme inhibitors in } \\
\text { pharmaceutical, cosmetics, and food industries }\end{array}$ & [45] \\
\hline 2 & $\begin{array}{l}\text { 3,7,11,15-Tetramethyl-2- } \\
\text { hexadecen-1-ol }\end{array}$ & 296 & 2.95 & 1.33 & & 2.52 & $\begin{array}{l}\text { anticancer, anti-inflammatory and antimicrobial,antioxidant } \\
\text { activities }\end{array}$ & {$[46]$} \\
\hline 3 & 1-Nonadecene & 266 & 1.10 & 3.14 & 6.02 & & Antimicrobial, antioxidant activity & {$[47,48]$} \\
\hline 4 & hexadecanoic acid, methyl ester & 270 & 21.28 & 11.77 & 3.87 & 5.30 & $\begin{array}{l}\text { Antioxidant, antimicrobial, hemolytic, hemolytic, 5-alpha } \\
\text { reductase inhibitor cancer enzyme inhibitors in pharma- } \\
\text { ceutical, cosmetics, and food industries }\end{array}$ & {$[45,49]$} \\
\hline 5 & $\begin{array}{l}\text { 9-octadecenoic acid (z)-, methyl } \\
\text { ester }\end{array}$ & 296 & 23.02 & 57.86 & 6.39 & 9.05 & $\begin{array}{l}\text { Antioxidant, antimicrobial, cancer enzyme inhibitors in } \\
\text { pharmaceutical, cosmetics, and food industries }\end{array}$ & $\begin{array}{l}{[45,49,} \\
50]\end{array}$ \\
\hline 6 & 1,2-benzenedicarboxylic acid & 390 & 3.16 & & 27.4 & 46.89 & $\begin{array}{l}\text { Antioxidant,antifouling, antimicrobial, cancer enzyme } \\
\text { inhibitors in pharmaceutical, cosmetics, and food } \\
\text { industries }\end{array}$ & {$[45,49]$} \\
\hline 7 & pentacosane & 352 & 9.97 & 3.48 & & & Antioxidant and antimicrobial activity & [51] \\
\hline 8 & dotriacontane & 450 & 2.11 & 2.83 & & 1.38 & $\begin{array}{l}\text { Antimicrobial, antifungal anti-inflammatory, cytotoxic } \\
\text { activity }\end{array}$ & [47] \\
\hline 9 & phthalic acid, butyl tetradecyl ester & 418 & & 7.41 & & 3.91 & Antimicrobial activity & {$[46]$} \\
\hline 10 & $\begin{array}{l}4 \text { h-1-benzopyran-4-one,2-(3, } \\
\text { 4dihydroxyphenyl)-6,8-di-á-d- } \\
\text { glucopyranosyl-5,7-dihydroxy- }\end{array}$ & 610 & & & 1.17 & 3.33 & $\begin{array}{l}\text { Antioxidant, antimicrobial, cancer enzyme inhibitors in } \\
\text { pharmaceutical, cosmetics, and food industries }\end{array}$ & {$[45]$} \\
\hline 11 & $\begin{array}{l}\text { 7,9-di-tert-butyl-1-oxaspiro } \\
\text { [4.5]deca-6,9-diene-2,8-dione }\end{array}$ & 276 & & 1.60 & 1.36 & & Antimicrobial activity & [52] \\
\hline 12 & 1-hexadecanol, 2-methyl- & 256 & & 1.71 & & & $\begin{array}{l}\text { anticancer, anti-inflammatory and antimicrobial,antioxidant } \\
\text { activities }\end{array}$ & {$[49]$} \\
\hline 13 & $\begin{array}{l}6,9,12,15 \text {-docosatetraenoic acid, } \\
\text { methyl ester }\end{array}$ & 346 & & & 1.79 & 4.18 & phytopharmaceutical importance & [53] \\
\hline 14 & Neophytadiene & 278 & 5.43 & 4.27 & 4.06 & & Antioxidant, antibacterial activity & [54] \\
\hline 15 & $\begin{array}{l}\text { Methyl } \\
4,7,10,13 \text {-hexadecatetraenoate }\end{array}$ & 262 & 3.61 & & & & Antioxidant, antibacterial activity & [54] \\
\hline 16 & Phytol & 296 & 12.08 & & & & Antioxidant, antibacterial activity & [54] \\
\hline 17 & $\begin{array}{l}\text { 9,12,15-octadecatrienoic acid,methyl } \\
\text { ester, }(z, z, z) \text { - }\end{array}$ & 292 & 14.49 & & & & Antimicrobial, antioxidant, anticancer & [45] \\
\hline 18 & heptanoic acid, docosyl ester & 438 & 0.93 & & & & Antioxidant and antifungal activity & {$[55]$} \\
\hline 19 & $\begin{array}{l}\text { 3,3,3-Trifluoro-1-piperidin-1-yl-2-trif } \\
\text { luoromethyl-propan-1-one }\end{array}$ & 263 & & 1.49 & & & & \\
\hline 20 & $\begin{array}{l}\text { 1,4-benzenediol, } \\
\text { 2-(1,1-dimethylethyl)-5-(2-propenyl)- }\end{array}$ & 206 & & 3.10 & & & Anticancer, Antioxidant activity and pesticidies & [56] \\
\hline 21 & 1,3-Dioxolane, 2-heptyl-4-phenyl- & 248 & & & 4.32 & & Anti-inflammatory, anticarcinogenic and ant aging & [57] \\
\hline 22 & Cycloheptasiloxane,tetradecamethyl- & 518 & & & 1.34 & & $\begin{array}{l}\text { antibacterial, antifungal, antifouling, immunomodulatory } \\
\text { and antitumor activities }\end{array}$ & [58] \\
\hline 23 & Corymbolone & 208 & & & 2.04 & & Antioxidant, antimicrobial activity & [59] \\
\hline 24 & $\begin{array}{l}\text { spiro[4.5]decan-7-one, } \\
\text { 1,8-dimethyl-8,9-epoxy-4-isopropyl- }\end{array}$ & 236 & & & 1.88 & & Anticancer activity & [60] \\
\hline 25 & $\begin{array}{l}\text { 8-(2-Acetyloxiran-2-yl)-6,6-dimethyl } \\
\text { octa-3,4-dien-2-one }\end{array}$ & 236 & & & 3.28 & & & \\
\hline 26 & $\begin{array}{l}\text { 03027205002 flavone } \\
\text { 4'-oh,5-oh,7-di-o-glucoside }\end{array}$ & 428 & & & 1.21 & & Antioxidant activity & [61] \\
\hline 27 & $\begin{array}{l}\text { 1,1'-bicyclopropyl]-2-octanoic acid, } \\
\text { 2'-hexyl-, methyl ester }\end{array}$ & 236 & & & 1.88 & & Anticancer activity & [53] \\
\hline 28 & $\begin{array}{l}\text { 2-acetyl-3-(2-cinnamido)eth } \\
\text { yl-7-methoxyindole }\end{array}$ & 362 & & & 2.03 & 1.31 & Antioxidant and antibacterial activity & [62] \\
\hline
\end{tabular}


Table $3 \mathrm{GC} /$ mass for most promising C. vulgaris fractions cultivated under Cu (0.316 mg/L) as relative percentage (Continued)

\begin{tabular}{|c|c|c|c|c|c|}
\hline 29 & $\begin{array}{l}\text { 1,2-benzenedicarboxylic acid, } \\
\text { bis(8-methylnonyl) ester }\end{array}$ & 446 & 3.35 & Antioxidant, antimicrobial, anticancer & [45] \\
\hline 30 & 13-docosenamide, (z)- & 337 & 24.85 & Antioxidant, antitumor activity & [63] \\
\hline 31 & 2,2-dideutero octadecanal & 270 & 2.01 & Antimicrobial activity & [47] \\
\hline 32 & $\begin{array}{l}\text { hexadecanoic acid, } \\
\text { 3[(trimethylsilyl)oxy] propyl ester }\end{array}$ & 386 & 3.65 & & \\
\hline 33 & $\begin{array}{l}\text { Hexanoic acid, 2-ethyl-,oxybis(2,1- } \\
\text { ethanediyloxy-2,1-ethane diyl) ester }\end{array}$ & 446 & 2.11 & & \\
\hline 34 & $\begin{array}{l}\text { 9,10-secocholesta-5,7,10(19)-triene-1, } \\
\text { 3-diol }\end{array}$ & 488 & 1.05 & Antiviral activity & [46] \\
\hline 35 & $\begin{array}{l}\text { S-(1,3-diphenylbutyl) } \\
\text { dimethylthiocarbamate }\end{array}$ & 311 & 2.06 & Antioxidant and anticancer activity & [64] \\
\hline 36 & Astaxanthin & 596 & 2.18 & Antioxidant activity & [65] \\
\hline
\end{tabular}

algal enzymes as reported by [47]. These results were in agreement with results obtained by [48] who reported that, copper is acutely toxic to Padina boergesenii at concentrations higher than $500 \mathrm{mg} \mathrm{Cu} / \mathrm{L}$. Moreover, low concentration of copper is toxic to $P$. boergesenii after a prolonged exposure of 21 days. Both growth and photosynthesis of Chlorella vulgaris were dependent on both concentration and exposure time under the influence of sub-lethal concentrations of the heavy metals $\mathrm{Cu}, \mathrm{Cr}, \mathrm{Zn}, \mathrm{Cd}$ and $\mathrm{Pb}[49]$.

The antioxidant activity of the promising extracts and fractions may be correlated to the presence of different active groups such as hydroxyl group and unsaturated bonds in the chemical structure of its compounds which showed high ability for scavenging free radicals and prevent the oxidation processes (as shown in Table 3), from the data of Table 3 We can conclude that the promising extract are rich with various bioactive compounds as antioxidant such as 4h-1-benzopyran-4one,2-(3,4-dimethoxyphenyl)-3,5-dihydroxy-7-methoxy, 3,7,11,15-Tetramethyl-2-hexadecen-1-ol, hexadecenoic acid, methyl ester, 9-octadecenoic acid (z)-, methyl ester, 1,2-benzenedicarboxylic acid, Neophytadiene, 9,12,15octadecatrienoic acid, methyl ester, (z,z,z)-, Astaxanthin. These observations were in agreement with the previously published studies [50-63].

Fractions (1, 5-7, and) exhibited the highest anticancer activity with the lowest $\mathrm{IC}_{50}$ values $(162.30$, $154.7,84.2,40.0 \mu \mathrm{g} / \mathrm{ml}$ respectively) as there is a strong correlation between anticancer activity and their richness contents of anticancer compounds as mentioned in Table 3 such as (4h-1-benzopyran-4-one, 2-(3, 4-dimethoxyphenyl)- 3, 5- dihydroxy-7-methoxy, 3,7,11,15-Tetramethyl-2-hexadecen-1-ol, hexadecanoic acid, methyl ester, 9-octadecenoic acid (z)-, methyl ester, 1,2-benzenedicarboxylic acid, dotriacontane, 1hexadecanol, 2-methyl, 1,3-Dioxolane, 2-heptyl-4phenyl, Cycloheptasiloxane, tetradecamethyl) as reported by many studies [64-71]. Regarding to cancer and synergy studies, Eichhornia sp. compounds have shown synergistic effect between them, especially on Hela cancer cell models [2]. Mohd Syahril [72] suggests that new anticancer natural products of chloroform extract from unicellular green algae (Chlorella sp) and filamentous microalgae (Spirulina $\mathrm{sp}$ ) are possible, Recently, the anticancer properties of some algae-derived resources have been found to modulate several cellular mechanisms such as cellular cytotoxicity, downregulate invasion of tumor cells, and enhancement of cancer cells apoptosis [73] C-Phycocyanin from microalgae Spirulina platensis has the ability to induce pathologic alteration and DNA fragmentation, upregulates Fas and ICAM expression, downregulates expression of $\mathrm{Bcl}-2$, as well as activation of caspases $2,3,4,6,8,9,10$ in HeLa cell line [74].

From the previous antioxidant and anticancer activities, Fraction 1, 5, 6 and 7 revealed the highest activity throughout. It was obvious that the antioxidant activity of fractions was higher than that showed by their original crude extract $(13.4,20.5 \mu \mathrm{g} / \mathrm{ml}$ against DPPH and ABTS respectively), it may be due to the synergistic effect between bioactive compounds that found in the fractions as recorded in Table 3 and antagonistic effect in crude extract.

Our results were parallel to those obtained by [75] They reported that apoptosis was 2.5 -fold higher in the case of the Chlorella sp. ethanol extract against human colon carcinoma cell line (HCT116) when compared with other microalgae strains. Moreover, [76] studied the interaction effect of herbal extract and ascorbic acid on antioxidant activity suggesting that antagonistic interaction between combination of either ascorbic acid and herbal extracts should be taken in consideration to prevent any health potential complications.

The isolated pure compound was recently extracted and identified from Chlorella vulgaris as reported by [77]. The antioxidant activity of this pure compound may be due to the presence of hydroxyl group and 

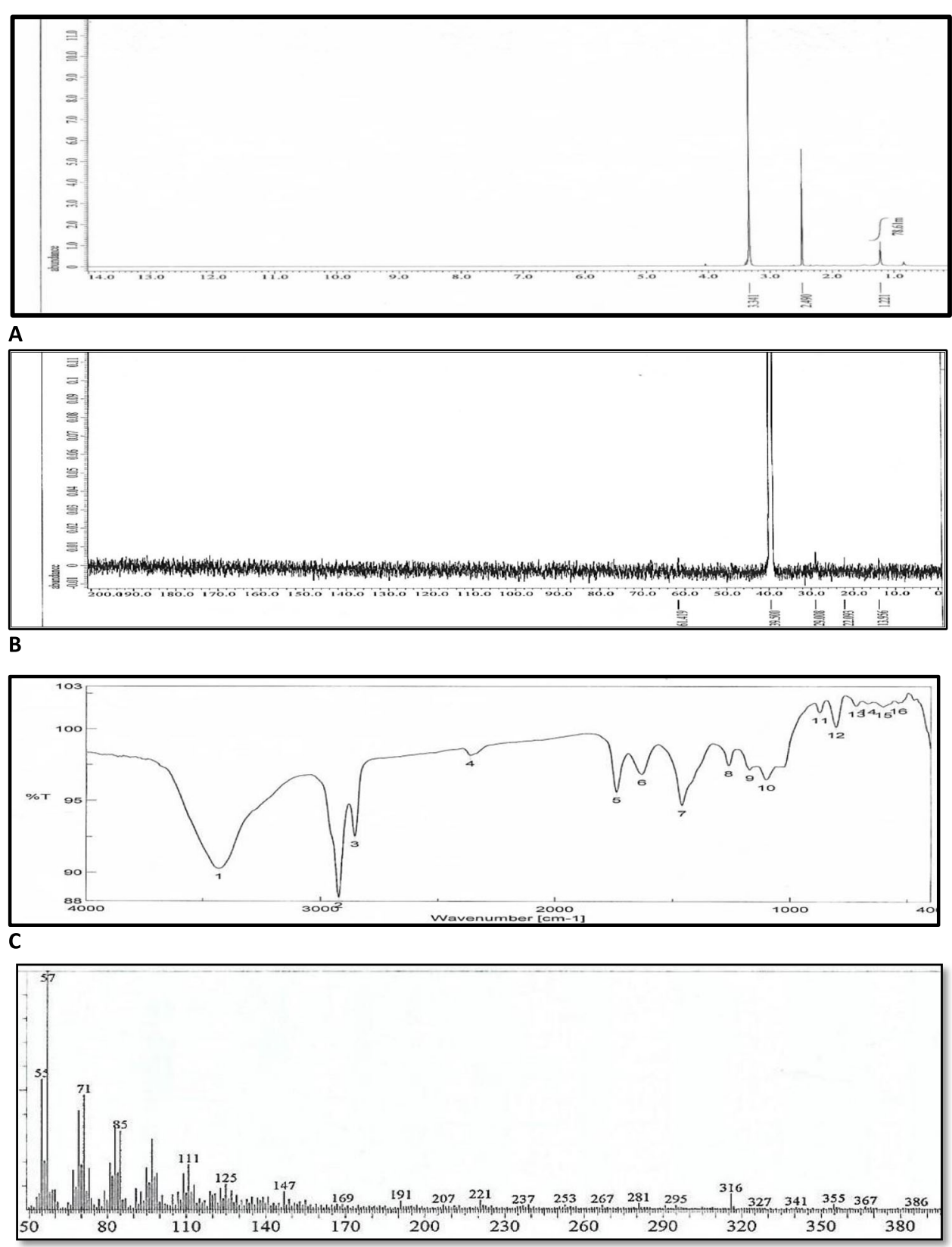

D

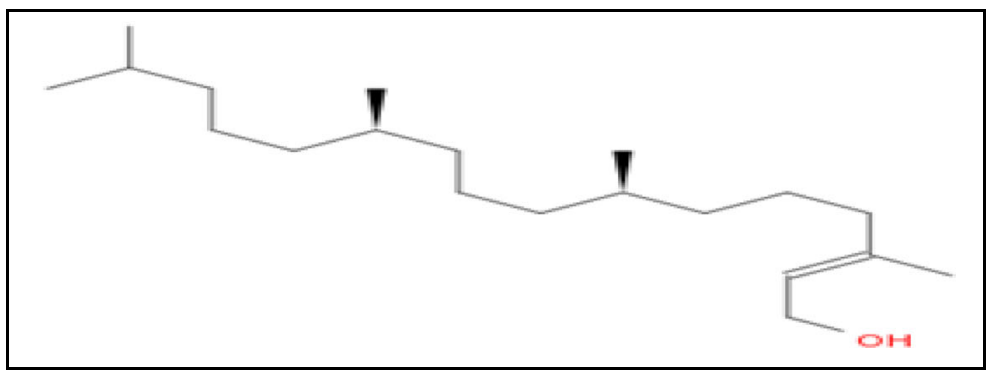

Fig. 4 H1-NMR spectrum (a); C13-NMR (b); IR-Spectrum (c); Mass spectrum (d); The chemical structure (e) of separated compound from Chlorella vulgaris 
Table 4 Antioxidant activity as (\% and $\left.I C_{50}\right)$ of isolated compound from C.vulgaris $(0.316 \mathrm{mg} / \mathrm{L} \mathrm{Cu})$ compared with (BHT) and (vitamin C) against DPPH (\%) radical method

\begin{tabular}{|c|c|c|c|c|c|c|}
\hline \multirow{2}{*}{$\begin{array}{l}\text { Compound } \\
\text { conc. } \\
\mu \mathrm{g} / \mathrm{ml} \\
(\mu \mathrm{g} / \mathrm{ml})\end{array}$} & \multicolumn{2}{|c|}{ Isolated compound } & \multicolumn{2}{|l|}{ BHT } & \multicolumn{2}{|l|}{ Vitamin C } \\
\hline & $30 \mathrm{~min}$. & $60 \mathrm{~min}$. & $30 \mathrm{~min}$. & $60 \mathrm{~min}$. & $30 \mathrm{~min}$. & $60 \mathrm{~min}$. \\
\hline 250 & $84.1 \pm 1.02^{\mathrm{a}}$ & $85.32 \pm 1.22^{\mathrm{a}}$ & $92.7 \pm 1.0^{\mathrm{a}}$ & $93.2 \pm 2.2^{\mathrm{a}}$ & $90.3 \pm 1.0^{\mathrm{a}}$ & $90.9 \pm 2.2^{\mathrm{a}}$ \\
\hline 125 & $76.99 \pm 1.1^{b}$ & $80.24 \pm 1.35^{b}$ & $90.3 \pm 0.9^{b}$ & $89.0 \pm 2.0^{b}$ & $88.8 \pm 0.9^{b}$ & $88.3 \pm 1.9^{b}$ \\
\hline 62.50 & $72.74 \pm 1.2^{c}$ & $77.04 \pm 1.24^{c}$ & $84.4 \pm 0.4^{c}$ & $84.9 \pm 2.0^{c}$ & $83.7 \pm 1.1^{c}$ & $85.9 \pm 1.0^{c}$ \\
\hline 31.25 & $69.6 \pm 1.9^{d}$ & $73.74 \pm 1.02^{d}$ & $72.7 \pm 0.5^{d}$ & $73.2 \pm 1.9^{d}$ & $68.2 \pm 0.7^{d}$ & $69.5 \pm 0.9^{d}$ \\
\hline 15.62 & $68 \pm 0.97^{d}$ & $73.74 \pm 1.00^{d}$ & $70.2 \pm 0.8^{d}$ & $69.4 \pm 1.2^{\mathrm{e}}$ & $64.4 \pm 0.5^{\mathrm{e}}$ & $63.0 \pm 0.9^{e}$ \\
\hline $\mathrm{IC}_{50}$ & 11.48 & 10.59 & 11.1 & 11.2 & 12.1 & 12.9 \\
\hline
\end{tabular}

Different small letters on the column for each time indicate significant difference $(p<0.05)$ Error bars represent \pm SD of three replicates

double bond which help for scavenging and react with radical species (ROS and RNS) as reported by Shanab et al. [53].

Also, these results were in agreement with the results obtained by Mohamed [51] who proved the antioxidant and anticancer activity of the crude extract continuing the pure bioactive compound (as indicated in GC/MS analyses). in addition to the results obtained by [78] who proved that, the methanolic extract of Kirganelia reticulata exhibited anticancer activity due to bioactive compounds separated from GC-MS analyses that include the pure compound ((2E,7R,11R)-3,7,11,15-Tetramethyl-2-hexadecenol). Additionally, the obtained results may be due to the prooxidant effect of isolated compound which led to increase the production of ROS and MDA of Hela cell line as shown in Fig. 6 A and B). These results were in agreement with results obtained by [79] who found that, some antioxidants act as prooxidants inducing nuclear damage and lipid peroxidation in presence of transition metal. Also, Seo and Lee [80] revealed that, some antioxidants have both prooxidant and antioxidant it can inhibit the proliferation of cancer cells. They also have shown antiproliferative effects on human colon, breast, prostate, and oral cancers. In addition to, some antioxidant compounds can act as pro-oxidant agent and increase the ROS production in cancer cell [81-84]. However, [83] revealed that those compounds are antioxidants in lower concentration but can be a pro-oxidant at a high level.

Accumulation of ROS disturbs the redox control of cell cycle progression through phosphorylation and ubiquitination of cell cycle proteins, resulting in aberrant cell proliferation and apoptosis [85]. Though ROS is dangerous to cells, the anticancer role of numerous treatments depends on their ability to encourage controlled ROS production, that changes cellular redox balance leading to oxidative stress, damage to mitochondria, and finally apoptosis induction [86], mitochondrial destabilization, caused by the increased ROS production, which in turn regulated the expression of apoptotic proteins. Pro-oxidant effect induced by polyphenols (as polyhydroxy compounds) led to generate ROS and produce [87] cell cycle arrest, and [88] induction of apoptosis and DNA fragmentation in cancer cells.

The anticancer potential of pure compound on Hela cells was proved through evaluating the expression of pro-apoptotic and anti-apoptotic genes. Data recorded in Fig. 7 revealed that pro-apoptotic genes $\mathrm{p}^{53}$, caspase 3 and Bax were significantly up-regulated/ over

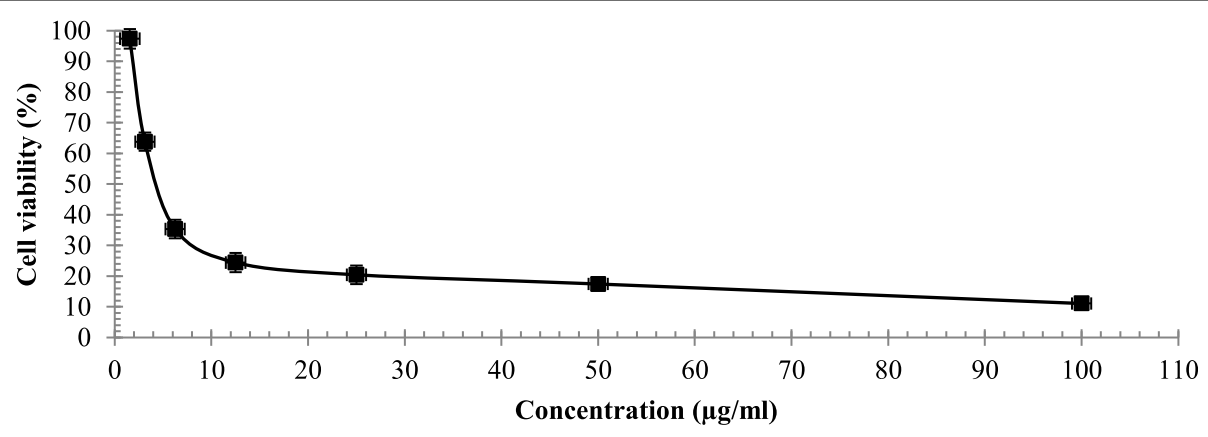

Fig. 5 cell viability (\%) of pure compound against Hel cell line with $I_{50}=4.38 \mu \mathrm{g} / \mathrm{ml}$ ) (Mean of three replicates) 


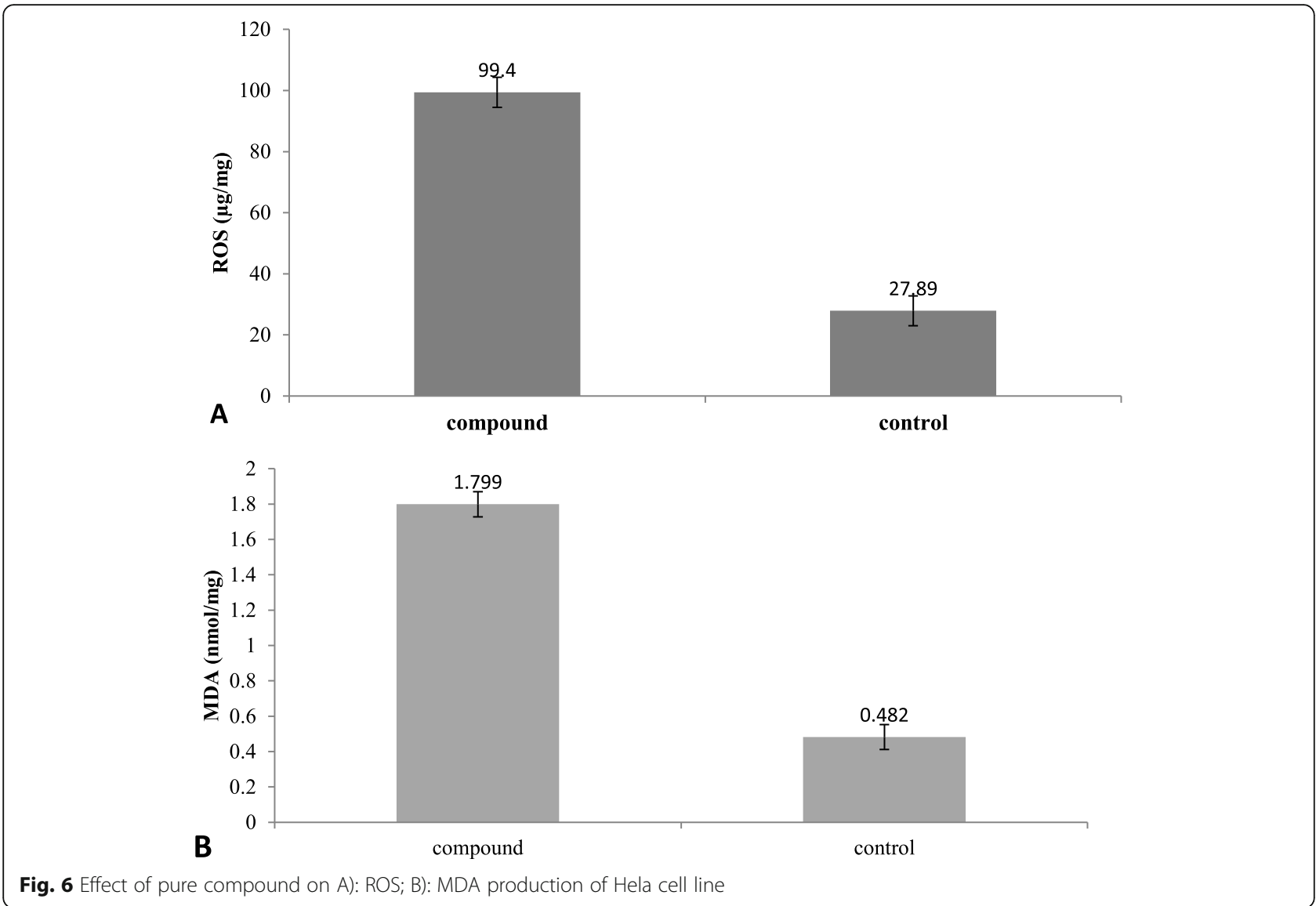

expressed after treatment with wheatgrass for $48 \mathrm{~h}$ compared to cell control values. Also, anti-apoptotic genes Fig. 7 showed that, the untreated control cells showed a normal spindle intact cells that wasn't clear in treated cells, where cells were detached showed ruptured membrane and irregular cell membrane. Bcl2 was significantly down-regulated compared to cell control values.
Apoptosis is a gene-regulated cell death mechanism with well-described biological changes [89]. A lot of bioactive compounds from algae can inhibit cancer cell growth through the induction of apoptosis; so, elucidating the mechanism of apoptosis has significant implication in cancer chemoprevention. Increased Bax expression can induce apoptosis and increased Bcl-2 expression which may inhibit apoptosis [90]. Bcl-2 proteins

\section{gene expression}

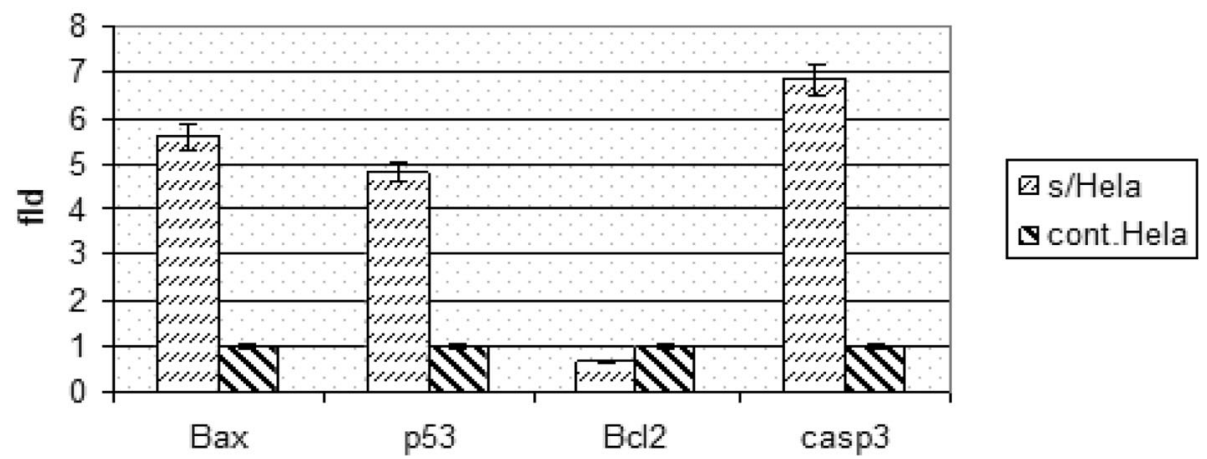

Fig. 7 Evaluation of pro-apoptotic and anti-apoptotic genes expression in Hela cell post treatment with pure compound for $48 \mathrm{~h}$ using real-time PCR compared to the non-treated cell control (Mean of three replicates.) 
prevent apoptosis by decreasing the cytochrome $\mathrm{C}$ release to inhibit activation of caspase 3 . However, Bax protein, helps in the transfer of cytochrome $\mathrm{C}$ across the membranes thus forming apoptotic bodies and activates both caspase 9 and caspase 3 that finally leads to apoptosis [91].

Increased ROS in cancer cells is also accompanying with the activation of a key signaling protein $\mathrm{p}^{53}$. Also, $\mathrm{p}^{53}$ accumulates in the nucleus and controls the pro apoptotic members expression, Bax and PUMA. Once up regulation of PUMA occurs, PUMA that binds to $\mathrm{Bcl}-2$, releasing $\mathrm{p}^{53}$ to activate Bax [92].

On the other hand, Fusi [93] reported the antioxidant compounds increases sirtuin 1 (SIRT1) expression and monophosphate activated protein kinase (MAPK) activation in Hela cell line. Safflower polysaccharide represents a major active component of Carthamus tinctorius. It inhibited proliferation and also increased apoptosis of Hela cells by down regulation of the phosphatidylinositol-3-kinase/ AKT pathway [94]. Additionally, Terminalia sericea enabled caspases-7 and -8 and poly (ADP-ribose) polymerase (PARP) in HeLa cancer cell line [83]. Also, pyrogallol induces superoxide anion, and this generates activation of caspase- 3 and phosphatidylserine [95].

Moreover, [96] evaluated the induction of apoptosis by isolated bioactive compounds (1-(2-hydroxyphenyl)-4methylpentan-1-one (C1) and 2-[(3-methylbutoxy) carbonyl] benzoic acid (C2)) from Rubus fairholmianus against MCF-7 breast cancer cells. Reactive oxygen species (ROS) production after treatment with $\mathrm{C} 1$ and $\mathrm{C} 2$ was found to be higher inducing nuclear damage. Expression of apoptotic proteins (caspase $9, \mathrm{p}^{53}$, and Bax) after the treatments was significantly up regulated as indicated using immunofluorescence.

\section{Conclusion}

The present study verifies the idea that oxidative stresses especially copper stress condition led to increase the biological activities of Chlorella vulgaris as antioxidant and anticancer, and these activities related to active ingredients increased in organic extract of algal species cultivated under stress condition and this due to alteration in gene expression of algal cells, the chromatographic and spectroscopic results proved the chemical structure of pure compounds as (2E,7R,11R)-3, 7,11,15-Tetramethyl-2-hexadecenol, and this compounds has high antioxidant and anticancer activity when compared with synthetic and natural standards. The author recommends cultivation of Chlorella vulgaris in large scale under various stress conditions for use the crude extracts and semi purified fractions for making a pharmaco-economic value in Egypt and other countries.

\section{Abbreviations}

ABTS: 2, 2'- azino-bis ethylbenzthiazoline-6-sulfonic acid; DMSO: Dimethyl sulfoxide; BHT: Butylated hydroxy toluene; DPPH: 2,2-diphenyl-1picrylhydrazyl; DOX: Doxorubicin; GC-MS: Gas chromatography-Mass spectrum; MAPK: Monophosphate activated protein kinase; MDA: Malondialdehyde; MTT: 3-(4,5-dimethylthiazol-2-yl)-2,5diphenyltetrazolium bromide; ROS: Reactive oxygen species; RT-PCR: Realtime Polymerase Chain Reaction; TLC: Thin layer chromatography

\section{Acknowledgements}

Not Applicable.

\section{Authors' contributions}

Conceived and designed the experiments: SMS EAS Performed the experiments: EAF SMS EAS. Collection of data: EAF, SMS, EAS Analyzed the data: SMS EAS HSG EAF, contributed reagents/materials/analysis tools: SMS EAS EAF HSG Wrote the paper: SMS EAS EAF HSG Revising of manuscript: SMS EAS EAF HSG. All authors read and approved the final manuscript.

\section{Funding}

This work was supported by Faculty of science and Faculty of Agriculture, Cairo University, Giza, Egypt (especially in biochemical analysis of extract and its fractions).

\section{Availability of data and materials}

The data used and analysed in this study are available from the corresponding author on reasonable request.

Ethics approval and consent to participate

Not applicable.

Consent for publication

Not applicable.

\section{Competing interests}

The authors declare that they have no competing interests.

\section{Author details}

${ }^{1}$ Department of Botany and Microbiology, Faculty of Science, Cairo University, Giza 12613, Egypt. ²Department of Biochemistry, Faculty of Agriculture, Cairo University, Giza 12613, Egypt. ${ }^{3}$ Department of Hormones. Medical Research Division, National Research Centre, Dokkie, Egypt.

Received: 26 October 2020 Accepted: 17 December 2020 Published online: 05 February 2021

\section{References}

1. Herrero M, Castro-Puyana M, Mendiola JA, Ibañez E. Compressed fluids for the extraction of bioactive compounds. Trends Anal Chem. 2013;43:67-83.

2. Aboul-Enein AM, Shanab SM, Shalaby EA, Zahran MM, Lightfoot DA, ElShemy HA. Cytotoxic and antioxidant properties of active principals isolated from water hyacinth against four cancer cells lines. BMC Complement Altern Med. 2014;14:397.

3. Al-Dabbagh B, Elhaty IA, Al Sakkaf R, El-Awady R, Ashraf SS, Amin A. Antioxidant and anticancer activities of Trigonella foenum-graecum, Cassia acutifolia and Rhazya stricta. BMC Complement Altern Med. 2018;22:240.

4. Al-Dabbagh B, Elhaty IA, Elhaw M, Murali C, Al Mansoori A, Awad B, et al. Antioxidant and anticancer activities of chamomile (Matricaria recutita L.). BMC Res Notes. 2019:3:3.

5. Amin A, Mahmoud-Ghoneim D. Texture analysis of liver fibrosis microscopic images: a study on the effect of biomarkers. Acta Biochim Biophys Sin Shanghai. 2011;43:193-203.

6. Newman DJ, Cragg GM. Natural products as sources of new drugs over the 30 years from 1981 to 2010. J Nat Prod. 2012:75:311-35.

7. Bajbouj K, Schulze-Luehrmann J, Diermeier S, Amin A, Schneider-Stock R. The anticancer effect of saffron in two p53 isogenic colorectal cancer cell lines. BMC Complement Altern Med. 2012;28(12):69.

8. Lin PY, Tsai CT, Chuang WL, Chao YH, Pan IH, Chen YK, et al. Chlorella sorokiniana induces mitochondrial-mediated apoptosis in human non-small cell lung cancer cells and inhibits xenograft tumor growth in vivo. BMC Complement Altern Med. 2017;17:88. 
9. Hamza AA, Heeba GH, Elwy HM, Murali C, El-Awady R, Amin A. Molecular characterization of the grape seeds extract's effect against chemically induced liver cancer: in vivo and in vitro analyses. Sci Rep. 2018;19:1270.

10. Ashktorab H, Soleimani A, Singh G, Amin A, Tabtabaei S, Latella G, et al. Saffron: the golden spice with therapeutic properties on digestive diseases. Nutrients. 2019;11(5):943.

11. El-Dakhly SM, Salama AA, Hassanin SO, Yassen NN, Hamza AA, Amin A. Aescin and diosmin each alone or in low dose-combination ameliorate liver damage induced by carbon tetrachloride in rats. BMC Res Notes. 2020;13:259.

12. Volk RB, Furkert FH. Antialgal, antibacterial and antifungal activity of two metabolites produced and excreted by cyanobacteria during growth. Microbiol Res. 2006;161:180-6.

13. Shalaby E. Algae as promising organisms for environment and health. Plant Signal Behav. 2011;9:1338-50.

14. Shanab SM, Mostafa SS, Shalaby EA, Mahmoud GI. Aqueous extracts of microalgae exhibit antioxidant and anticancer activities. Asian Pac J Trop Biomed. 2012;2:608-15.

15. Shalaby EA, Dubey NK. Polysaccharides from cyanobacteria: response to biotic and abiotic stress and their antiviral activity. Indian J Geo-Mar Sci. 2018;47:21-33.

16. Philia J, Wibisono J. Cultivation of microalgae chlorella sp on fresh water and waste water of tofu industry. InE3S Web Conf. 2018;31:04009 EDP Sciences.

17. Abu-Serie MM, Habashy NH, Attia WE. In vitro evaluation of the synergistic antioxidant and anti-inflammatory activities of the combined extracts from Malaysian Ganoderma lucidum and Egyptian Chlorella vulgaris. BMC Complement Altern Med. 2018;18:154.

18. Lauritano C, De Luca D, Amoroso M, Benfatto S, Maestri S, Racioppi C, et al. New molecular insights on the response of the green alga Tetraselmis suecica to nitrogen starvation. Sci Rep. 2019;9:3336.

19. Barbosa-Filho JM, Alencar AA, Nunes XP, Tomaz AC, Sena-Filho JG, AthaydeFilho PF, et al. Sources of alpha-, beta-, gamma-, delta-and epsiloncarotenes: A twentieth century review. Rev Bras Psiquiatr. 2008;18:135-54.

20. Brito da Matta CB, De Souza ÉT, De Queiroz AC, De Lira DP, De Araújo MV, Cavalcante-Silva LH, et al. Antinociceptive and anti-inflammatory activity from algae of the genus Caulerpa. Mar Drugs. 2011:9:307-18.

21. Alves C, Silva J, Pinteus S, Gaspar H, Alpoim MC, Botana LM, et al. From marine origin to therapeutics: the antitumor potential of marine algaederived compounds. Front Pharmacol. 2018;9:777.

22. Calcabrini C, Catanzaro E, Bishayee A, Turrini E, Fimognari C. Marine sponge natural products with anticancer potential: an updated review. Mar Drugs. 2017;15:310

23. A Ratovitski E. Anticancer natural compounds as epigenetic modulators of gene expression. Curr Genomics. 2017;18:175-205

24. Baudelet PH, Gagez AL, Bérard JB, Juin C, Bridiau N, Kaas R, et al. Antiproliferative activity of Cyanophora paradoxa pigments in melanoma, breast and lung cancer cells. Mar Drugs. 2013;11:4390-406.

25. Ndjouondo GP, Dibong SD, Wamba FO, Taffouo VD. Growth, productivity and some physico-chemical factors of Spirulina platensis cultivation as influenced by nutrients change. Int J Bot. 2017;13:67-74.

26. Zappi ME, Bajpai R, Hernandez R, Mikolajczyk A, Lord Fortela D, Sharp W, et al. Microalgae culturing to produce biobased diesel fuels: an overview of the basics, challenges, and a look toward a true biorefinery future. Ind Eng Chem Res. 2019;58:15724-46.

27. Zouari M, Ahmed CB, Elloumi N, Bellassoued K, Delmail D, Labrousse P, et al. Impact of proline application on cadmium accumulation, mineral nutrition and enzymatic antioxidant defense system of Olea europaea L. cv Chemlali exposed to cadmium stress. Ecotoxicol Environ Saf. 2016;128:195-205.

28. Olivares HG, Lagos NM, Gutierrez CJ, Kittelsen RC, Valenzuela GL, Lillo ME. Assessment oxidative stress biomarkers and metal bioaccumulation in macroalgae from coastal areas with mining activities in Chile. Environ Monit Assess. 2016:188:25.

29. Ozdemir G, Ulku Karabay N, Dalay MC, Pazarbasi B. Antibacterial activity of volatile component and various extracts of Spirulina platensis. Photother Res. 2004;18:754-7.

30. Sabatini SE, Juárez ÁB, Eppis MR, Bianchi L, Luquet CM, de Molina MD. Oxidative stress and antioxidant defenses in two green microalgae exposed to copper. Ecotoxicol Environ Saf. 2009:72:1200-6.

31. Machado MD, Soares EV. Short-and long-term exposure to heavy metals induced oxidative stress response in Pseudokirchneriella subcapitata. CleanSoil, Air, Water. 2016;44:1-6.
32. Pandey R, Zinta G, AbdElgawad H, Ahmad A, Jain V, Janssens IA. Physiological and molecular alterations in plants exposed to high $\left[\mathrm{CO}_{2}\right]$ under phosphorus stress. Biotechnol Adv. 2015;33:303-16.

33. Prescott GW. How to know fresh water algae. Dubuque: Brown company publishers; 1978. p. 12-267.

34. Prescott GW. Algae of the Western great lakes area W.M.C. Dubuque: Brown publishers; 1982. p. 1-977.

35. Stanier RY, Kunisawa R, Mandel M, Cohen-Bazire G. Purification and properties of unicellular blue-green algae (order Chroococcales). Bacteriol Rev. 1971:35:171-205.

36. Andersen RA. Algal culturing techniques. New York: Phycological society of America, Academic press in an imprint of Elseviver. Academic Press; 2005. 578 p.

37. Yen GC, Chen HY. Antioxidant activity of various tea extracts in relation to their antimutagenicity. J Agric Food Chem. 1995;43:27-37.

38. Re R, Pellegrini N, Proteggente A, Pannala A, Yang M, Rice-Evans C. Antioxidant activity applying an improved ABTS radical cation decolorization assay. Free Radic Biol Med. 1999;26:1231-7.

39. El-Far M, Elmegeed GA, Eskander EF, Rady HM, Tantawy MA. Novel modified steroid derivatives of androstanolone as chemotherapeutic anti-cancer agents. Eur J Med Chem. 2009:44:3936-46.

40. Maurya DK, Nandakumar N, Devasagayam TP. Anticancer property of gallic acid in A549, a human lung adenocarcinoma cell line, and possible mechanisms. J Clin Biochem Nutr. 2011;48:85-90.

41. Banday AA, Lokhandwala MF. Renal dopamine oxidation and inflammation in high salt fed rats. J Am Heart Assoc. 2020;9:e014977.

42. Hussein A. Comparative evaluation of anticancer potential of Moringao leifera, Ganoderma lucidum and silver nanoparticles against breast and liver cancer cell lines and related pro and anti apoptotic genes profile. Int J Sci Res Manag. 2017:5:5242-52.

43. Wilfinger WW, Mackey K, Chomczynski P. Effect of pH and ionic strength on the spectrophotometric assessment of nucleic acid purity. Biotechniques. 1997:22:474-81.

44. Huang DS, Irwin GW. Computational intelligence: international conference on intelligent computing, ICIC 2006, Kunming, China, August 16-19, 2006, proceedings. Berlin, Heidelberg: Springer-Verlag; 2006.

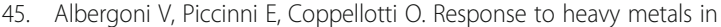
organisms-l. excretion and accumulation of physiological and nonphysiological metals in Euglena gracilis. Comp Biochem Physiol. 1980;67:121

46. Rijstenbil JW, Dehairs F, Ehrlich R, Wijnholds JA. Effect of the nitrogen status on copper accumulation and pools of metal-binding peptides in the planktonic diatom Thalassiosira pseudonana. Aquat Toxicol 1998;42:187-209

47. Harris ED. Copper as a cofactor and regulator of copper, zinc superoxide dismutase. J Nutr 1992;122:636-40.

48. Mamboya F, Pratap HB, Mtolera M, Bjork M. The effect of copper on the daily growth rate and photosynthetic efficiency of the brown macroalga Padina boergesenii. In: Richmond MD, Francis J, editors. Marine science development in Tanzania and eastern Africa: Proceedings of the 20th Anniversary Conference on Advances on Marine Sciences in Tanzania 28 June- 1 July 1999. Zanzibar: IMS, Zanzibar (Tanzania) pp; 2001. p. 185-92.

49. Ouyang H, Kong X, He W, Qin N, He Q, Wang Y, et al. Effects of five heavy metals at sub-lethal concentrations on the growth and photosynthesis of Chlorella vulgaris. Chin Sci Bull 2012;57:3363-70.

50. 50. SAYIK A, YUSUFOĞLU AS, Leyla AÇ, TÜRKER G, AYDIN B, ARSLAN L. DNAbinding, biological activities and chemical composition of wild growing Epilobium angustifolium L. extracts from Canakkale, Turkey. J Turkish Chem Soc Sect. 2017:4:811-40.

51. Mohamed AA, Ali SI, Darwesh OM, El-Hallouty SM, Sameeh MY. Chemical compositions, potential cytotoxic and antimicrobial activities of Nitraria retusa methanolic extract sub-fractions. Int J Toxicol Pharmacol Res 2015;7: 204-12.

52. Yasa N, Masoumi F, ROUHANI RS, HAJI AA. Chemical composition and antioxidant activity of the extract and essential oil of Rosa damascena from Iran, population of Guilan. J Pharm Sci 2015;17:175-80.

53. Shanab SM, Shalaby EA, El-Fayoumy EA. Enteromorpha compressa exhibits potent antioxidant activity. J Biomed Biotechnol 2011;2011:726405.

54. Sosa AA, Bagi SH, Hameed IH. Analysis of bioactive chemical compounds of Euphorbia lathyrus using gas chromatography-mass spectrometry and fourier-transform infrared spectroscopy. J Pharmacogn Phytother 2016;8: 109-26.

55. Marrufo T, Nazzaro F, Mancini E, Fratianni F, Coppola R, De Martino L, et al. Chemical composition and biological activity of the essential oil from leaves 
of Moringa oleifera lam. Cultivated in Mozambique. Molecules. 2013;18(9): 10989-1000.

56. 56. Swamy MA. Marine algal sources for treating bacterial diseases. Adv Food Nutr Res 2011;64:71-84.

57. Wintola OA, Afolayan AJ. Chemical constituents and biological activities of essential oils of Hydnora africana thumb used to treat associated infections and diseases in South Africa. Appl Sci 2017;7:1-14.

58. Manorenjitha MS, Norita AK, Norhisham S, Asmawi MZ. GC-MS analysis of bioactive components of Ficus religiosa (Linn.) stem. Int J Pharm Bio Sci 2013;4(2):99-103.

59. Azzaz NAE, El-Khateeb AY, Farag AA. Chemical composition and biological activity of the essential oil of Cyperus articulates. Inte J Acad Res. 2014;6:265-9.

60. Rice-Evans CA, Miller NJ, Paganga G. Structure-antioxidant activity relationships of flavonoids and phenolic acids. Free Radic Biol Med 1996;20: 933-56.

61. Jitareanu A, Tataringa G, Zbancioc AM, Tuchilus C, Balan M, Stanescu U. Cinnamic acid derivatives and 4-aminoantipyrine amides-synthesis and evaluation of biological properties. Res J Chem Sci. 2013;3:9-13.

62. ChunYan H, Hong P, ZhenYu Z, Jing S. Evaluation of antioxidant and antitumour activities of lemon essential oil. J Med Plant Res 2010;4:1910-5.

63. Naguib YM. Antioxidant activities of astaxanthin and related carotenoids. J Agric Food Chem 2000;48:1150-4.

64. Cherchi G, Deidda D, Gioannis BD, Marongiu B, Pompei R, Porcedda S. Extraction of Santolina insularis essential oil by supercritical carbon dioxide: influence of some process parameters and biological activity. Flavour Fragr J 2001;16:35-43.

65. Aly AA, Maraei RW, Ali HG. Fatty acids profile and chemical composition of Egyptian Moringa oleifera seed oils. J Am Oil Chem Soc 2016;39:397-404.

66. Srivastava R, Mukerjee A, Verma A. GC-MS analysis of Phytocomponents in, pet ether fraction of wrightia tinctoria seed. Pharm J 2015;7:249-53.

67. Jeeshna MV, Paulsamy S. Phytochemistry and bioinformatics approach for the evaluation of medicinal properties of the herb, Exacum bicolor Roxb. Int Res J Pharm 2011;2:163-8.

68. Patil A, Jadhov V. GC-MS analysis of bioactive components from methanol leaf extract of Toddaliaasiatica (L.). Int J Pharm Sci Rev Res 2014;29(1):18-20.

69. Flefel EM, El-Sayed WA, Mohamed AM, El-Sofany WI, Awad HM. Synthesis and anticancer activity of new 1-thia-4-azaspiro [4.5] decane, their derived thiazolopyrimidine and 1, 3, 4-thiadiazole thioglycosides. Molecules. 2017; 22(1):170.

70. Adeyemi JO, Onwudiwe DC, Ekennia AC, Anokwuru CP, Nundkumar N, Singh $\mathrm{M}$, et al. Synthesis, characterization and biological activities of organotin (IV) diallyl dithiocarbamate complexes. Inorg Chim Acta 2019;485:64-72.

71. Radhakrishnan S, Reddivari L, Sclafani R, Das UN, Vanamala J. Resveratrol potentiates grape seed extract induced human colon cancer cell apoptosis. Front Biosci (Elite Ed). 2011;3:1509-23.

72. Mohd-Syahril MZ, Roshani O, Nurhasyimah R, Mohamad Hafiz MS, Sharida $M D$, Ahmed HY. Screening of anticancer activities of crude extracts of unicellular green algae (Chlorella vulgaris) and filamentous blue green algae (Spirulina platensis) on selected cancer cell lines. In: International conference on applied sciences, mathematics and humanities; 2011.

73. Talero E, García-Mauriño S, Ávila-Román Rodríguez-Luna A, Alcaide A, Motilva V. Bioactive. Compounds isolated from microalgae in chronic inflammation and cancer. Mar Drugs. 2015;13:6152-209.

74. Medina RA, Goeger DE, Hills P, Mooberry SL, Huang N, Coibamide A. Potent antiproliferative cyclic depsipeptide from the Panamanian marine cyanobacterium Leptolyngbya sp. J Am Chem Soc. 2008;130:6324-5.

75. Kwang HC, Song YIK, Lee DU. Antiproliferative effects of carotenoids extracted from Chlorella ellipsoidea and Chlorella vulgaris on human colon cancer cells. J Agric Food Chem. 2008;56:10521-6.

76. Singprecha A, Yarovaya L, Khunkitti W. The interaction effect of ginger extract and ascorbic acid on antioxidant activity. J Sci Technol. 2019;SJST:5-32.

77. Lafarge C, Cayot N. Insight on a comprehensive profile of volatile compounds of Chlorella vulgaris extracted by two "green" methods. Food Sci Nutr. 2019;7:897-1143.

78. Reddy RA, Krishna V, Usha S, Bharathi R, Murthy VK. GC-MS analysis of methanolic extract of stem and root bark of Kirganelia reticulata for bioactive components. J Fundam Appl Sci. 2017;6:8-13.

79. Cao G, Sofic E, Prior RL. Antioxidant and prooxidant behavior of flavonoids: structure-activity relationships. Free Radic Biol Med. 1997;22:749-60.
80. Seo MY, Lee SM. Protective effect of low dose of ascorbic acid on hepatobiliary function in hepatic ischemia/reperfusion in rats. J Hepatol. 2002;36:72-7.

81. Amawi H, Ashby CR, Samuel T, Peraman R, Tiwari AK. Polyphenolic nutrients in cancer chemoprevention and metastasis: role of the epithelial-tomesenchymal (EMT) pathway. Nutrients. 2017;9(8):911.

82. Sánchez-Carranza JN, Díaz JF, Redondo-Horcajo M, Barasoain I, Alvarez L, Lastres $P$, et al. Gallic acid sensitizes paclitaxel-resistant human ovarian carcinoma cells through an increase in reactive oxygen species and subsequent downregulation of ERK activation. Oncol Rep. 2018;39:3007-14.

83. Gu B, Shalom J, Cock IE. Anti-proliferative properties of terminalia sericea burch. Ex dc leaf extracts against Caco2 and HeLa cancer cell lines. Pharm J. 2018;10:408-15.

84. Jaradat N, Al-Lahham S, Abualhasan MN, Bakri A, Zaide H, Hammad J, et al. Chemical constituents, antioxidant, cyclooxygenase inhibitor, and cytotoxic activities of Teucrium pruinosum boiss, Essential oil. Biomed Res Int. 2018; 2018:4034689.

85. Verbon EH, Post JA, Boonstra J. The influence of reactive oxygen species on cell cycle progression in mammalian cells. Gene. 2012;511:1-6.

86. Engel RH, Evens AM. Oxidative stress and apoptosis: a new treatment paradigm in cancer. Front Biosci. 2006;11:300-12.

87. Stull MA, Rowzee AM, Loladze AV, Wood TL. Growth factor regulation of cell cycle progression in mammary epithelial cells. J Mammary Gland Biol Neoplasia. 2004;9:11.

88. Witsch E, Sela M, Yarden Y. Roles for growth factors in cancer progression. Physiology (Bethesda). 2010;25:85-101.

89. Brown JM, Attardi LD. The role of apoptosis in cancer development and treatment response. Nat Rev Cancer. 2005;5:231-7.

90. Zheng JH, Viacava Follis A, Kriwacki RW, Moldoveanu T. Discoveries and controversies in BCL-2 protein-mediated apoptosis. The FEBS J. 2016;283(14): 2690-700.

91. Julien O, Wells JA. Caspases and their substrates. Cell Death Dis. 2017;24:1380-9.

92. Wu CS, Gao QH, Kjelgren RK, Guo XD, Wang M. Yields, phenolic profiles and antioxidant activities of Ziziphus jujube mill. In response to different fertilization treatments. Molecules. 2013;18(10):12029-40.

93. Fusi J, Bianchi S, Daniele S, Pellegrini S, Martini C, Galetta F, et al. An in vitro comparative study of the antioxidant activity and SIRT1 modulation of natural compounds. Biomed Pharmacother. 2018;101:805-19.

94. Yang J, Wang R, Feng Q, Wang YX, Zhang YY, Wu WH, et al. Safflower polysaccharide induces cervical cancer cell apoptosis via inhibition of the PI3KJAkt pathway. S Afr J Bot. 2018;118:209-15.

95. Bruges G, Venturini W, Crespo G, Lopez-Zambrano M. Pyrogallol induces apoptosis in human platelets. Folia Biol. 2018;64:8.

96. George BP, Abrahamse $\mathrm{H}$. Increased oxidative stress induced by rubus bioactive compounds induce apoptotic cell death in human breast cancer cells. Oxid Med Cell Longev. 2019;2019:18.

\section{Publisher's Note}

Springer Nature remains neutral with regard to jurisdictional claims in published maps and institutional affiliations.

Ready to submit your research? Choose BMC and benefit from:

- fast, convenient online submission

- thorough peer review by experienced researchers in your field

- rapid publication on acceptance

- support for research data, including large and complex data types

- gold Open Access which fosters wider collaboration and increased citations

- maximum visibility for your research: over $100 \mathrm{M}$ website views per year

At $\mathrm{BMC}$, research is always in progress.

Learn more biomedcentral.com/submissions 